\title{
家鬼二於ケル肺炎，成生亚免疫二關スル 實驗的研究
}

\section{越智勇一今井 信 實}

（朝鮮總督府獸疫血清製造所 所長：昆野博士）

(昭和 11 年 11 月 24 日受附)

目

緒 言

I. 肺资成生二關スル試驗

A. 强毒菌種 B，全種キ以テセ 儿場合

B. 强毒菌種 L。一部及同種菌 キ以テセル場合

C. 弱毒菌種 S. 江原キ以テセ 儿㛫合

D. 弱毒菌種 Bacterium bronchisepiicus 7 以テセル場合

II. 肺桨ノ免疫二關スル試驗
次

- A. 强嗉菌種 (B. 全種) 感染= 對スル免疫

B. 强莓菌種 (L.一部及同種 菌) 感染二對スル免疫

C. 弱毒菌種 $(\mathrm{S}$. 江原) 感染 $=$ 對スル免疫

D. 弱毒菌種 (Bact. bronchisepticus）感染二對スル免阌

III. 總括及結諭

主要文獻

\section{緒言}

種ぬナル病原菌 $=ヨ ル$ 肺炎, 肋膜炎, 氣管枝炎, 鼻炎等ノ呼吸器傳病及ビ 是二隨伴シテ發生シ若シク八單獨二發生スル刑桃腺炎，耳下腺炎，中耳炎， 顎凹部淋巴腺炎等〉傳染性疲患八洽ク人畜二發生シ家畜二於テ特=注目 二值スルモノ=牛豚ノ野獸牛疫, 豚ノ豚疫,羊ノ肺炎,家鬼ノ肺炎及すなつ ふる症, 馬つ腺炎等アリ而シテ此等種くナル疲患ノ本態郎千其病原體, 病 理發生等ニ關シテハ既二精細ナル研究業績アリテ何レモ解沃セラレ居ルモ 何未だ此等疾患二就テハ充分解決セラレザルモノ、如ク而シテ其原因多々 アル可キモ是ガ䆬驗的研究二際シ菌對動物ノ關係ノ相異ニヨル Krankheitsform ノ差異二就テ考慮七ラル、コト少ナキ八重要ナル一因子ナリト思 考セラル

余等此點二鑑ミ特=Krankheitsform =重キシ置キ如上疾患 /免疫＝就: 
テ瓷驗的研究ヨ行ヒツ、アルモ先ヅ家鬼二就テ主トシテ出血性敗血症菌ヨ

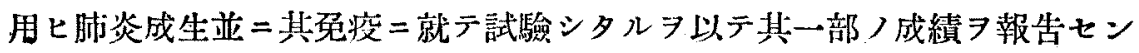
小又份本報二於テハ主トシテ細菌學的試驗二就テ記载シ痕理學的試驗＝就， テ八後述スル豫定ナリ

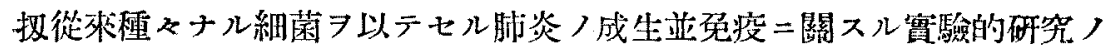
報告入既二枚擧ニ追アラザルモ今主ナルモノフ摘錄スルニ先ヅ Wollstein, Martha \& Meltzer (1912) $)^{(1)}$ 八犬二就平溶血性速䥊狀球菌，いんふるえ んざ菌混合培養, 筷管內注入法 $=$ ヨル大葉性氣管枝肺炎, 成生二就方記载 \& Winternitz u. Hirschfelder (1913) ${ }^{(2)}$ 八家鬼二就實驗的肺炎 つ精細

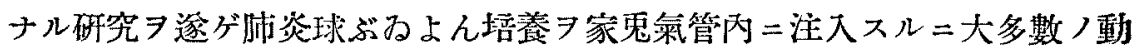
物八 24-72 時間二テ整レ每例必ズ大葉性肺炎並乾性肋膜炎 7 發生スル 認メ又此種脯炎免疫二就テハ同菌少量/反復氣管內感染ニヨリテ澾セラル

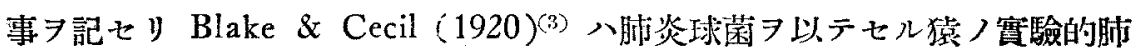
炎二於テ研究肺炎〉成生法並病變二於テ八W Winternitz 等卜同梯ナル事

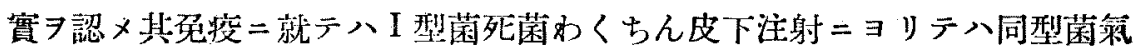
管內感染及 IV 型菌/自然感染 7 防禦シ得ザリシモ感染菌)血行內侵入 7 防遏シ檌患動物ノ經過タ綬慢ナラシメ得タリトGay \& Rhodes (1921)(4) 及 Permar $(1923)^{(5)}$ 八夫ょ家鬼二溶連菌及肺炎球菌氣管內注入シ定型 的大葉性肺炎 7 發生セシメ叉山林 $(1923)^{(6)}$ 八Fränkel氏肺炎球菌及 Pfeiffer 氏几んふるえんざ菌）家鬼策管內注射 $=ヨ$ 几筫驗的肺炎 $习$ 研究シ大菲

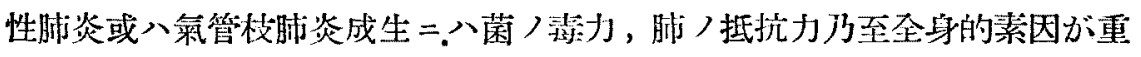
要ナル因子ナル事习指摘七り Johnes (1924)(7) モ亦Pasteurella aviseptica

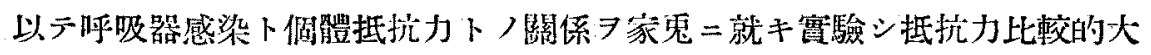

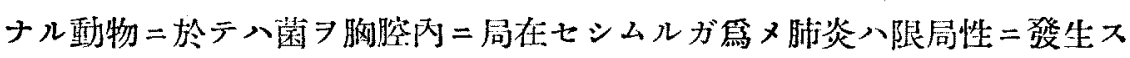

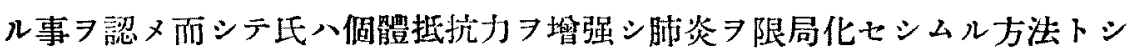
テ死菌わくちん=ヨル不完全免疫行ヒタリ中山 $(1934)^{3)}$ 八肺炎球菌 I

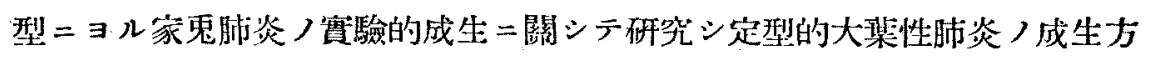
法トシテ胸腔内注射ノ優秀ナルク報ぜり Stillman \& Schulz (1935) $)^{(9)}$ 八 


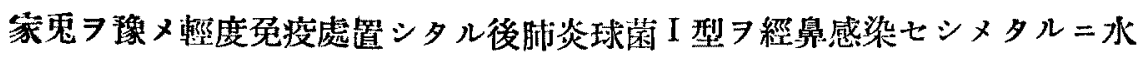

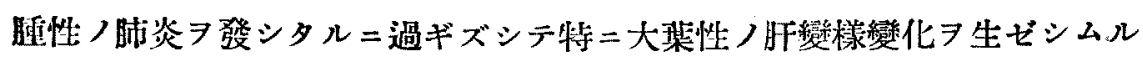
事能ハザリキト月中 $(1926)^{(10)}$ 八家鬼すなつふる症ノ砄究

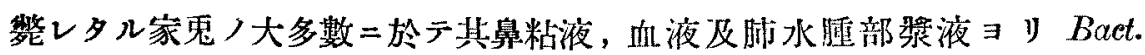
lepisepticus 7 少數例二於テ Bact. bronchieepticus 7 純粹二分離シ是等分離

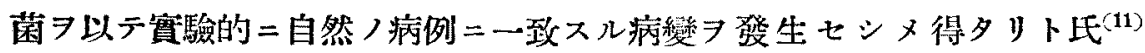

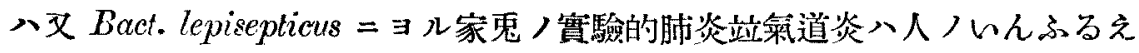
んさ肺炎，所見二酷似七ル事

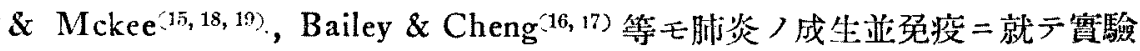

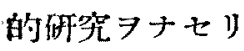

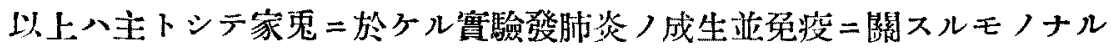

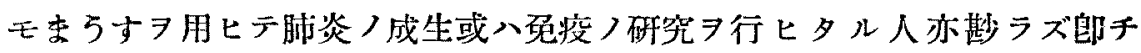
Stillman \& Branch (1924) 20 八まうす

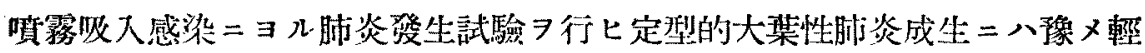

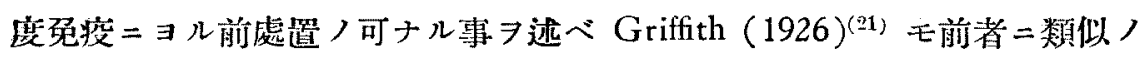

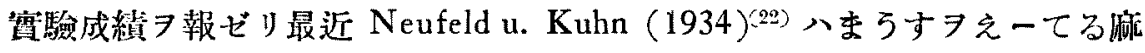
醉シ肺炎球菌. Friedländer 氏肺炎程菌，出血性稘血症菌，Bact.bronchisepticus ノ經鼻或八胸腔內接種=ヨリ定型的郝炎 ゼり

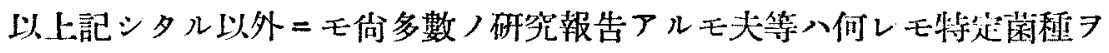

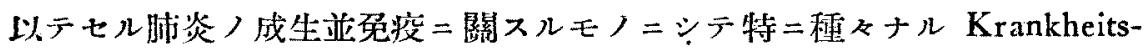
foum ト犬二對スル免没二就テ屍虑セラレタルモノナキガ如シ余等い此點

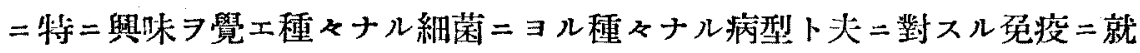
テ實驗习企テタルナリ

\section{I. 肺炎成生ニ關スル試驗}

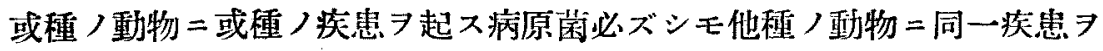
發症セシムルモノニ非ザル事八周知ノ事害ニシテ總テ菌数動物ノ關係ヨ考 
虑スルニ非ザレバ同一病原菌ヨ以テ試驗スルモ必ズシモ同一疾患ヨ發生七 シムル事能ハズ此事實八殊 =小試驗動物 7 月用七テ種ネナル疾病二關スル筫 驗的研究アナス際最モ考慮スベキ事ナル可シ

余等ガ本試驗ノ目的トスル處八廣ク自然界=發生スル種ふナル細菌二因 ル種くナル動物ノ呼吸器疾患（主トシテ肺炎）例へバ野獸牛疫, 豚疫, 家

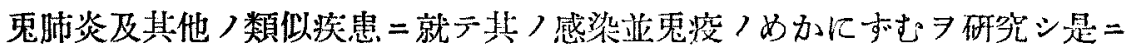
ヨリテ如上疾患ノ免疫二就テ避當ナル力策ヨ案出セントスルニアルモ直接 牛豚等二就テ實驗スル事能ヘザル

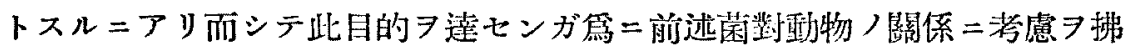
ヒ成ル可ク多數ノ菌種

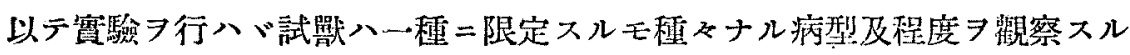
事ヨ得ベク其內該當スベキ何レカ $=ヨ リ テ$ 自然界=發生スル種ぬナル菌

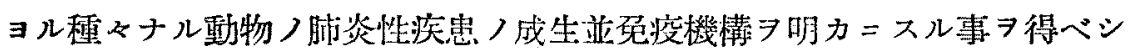
ト思考シタレバナリ但シ本報ニ八下記ノ菌種ヨ以テ行ヒタル實驗成續=就 テ記载シ其他ノ菌種 機會アラン事ヨ期七リ

使用菌種

1. 所謂野獸牛疫菌 (B. 全種)

2. 所謂豚度菌（S. 江原）

3. Bacterium bronchisepticus (Br. III)

4. 所謂家鬼敗血症菌 (L. 一部及其他)

以上入內 $\mathrm{B}$. 全種八豚ヨリ分離七ル Pasteurella = シテ越智(23)，所謂 $\mathrm{B}$ 型二屬シ畨ダ毒性强っS. 汇原八同梯豚ヨリ分離七儿越智ノ所謂 $\mathrm{C}$ 型二屬 スル Pasteurella =シテ詰性比較的弱》 Br. III 八健康家鬼 $=ヨ$ リ分離七 ル Brucella =シテ毒性弱ク又 L. 一部及其他八同種菌八家鬼肺炎ヨリ分 離セル Pasteurella ニシテ毒性强キモノナリ（本菌／分類其他二就テハ別 途報告スル豫定ナリ)

䔈驗方法 
實驗動物八總テ體重 $2 \mathrm{~kg}$ 內外ノ家鬼ニシテ全部動物商ヨリ睡入シタル モノナルモ使用前㷁メ1 万月內外當所二聚留シ健康ナル シタリ感染動物つ觀察期聞八概ネ 3 週間トシ其期間內二發病䩦死シタルモ

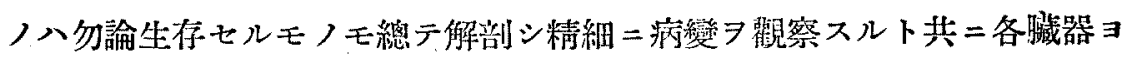
リ唔養 $ヨ$ 行七接種菌ノ存否 7 檢素シタリ其他ノ點=就テハ其都度本文中ノ 記載ス可シ

A. 强素菌種 (B. 全種) 7 以テセル場合

本試驗二用ヒタル B. 全種八前述ノ如ク出血性敗血症菌屬中〉越智ノ所 謂 $\mathrm{B}$ 型菌株ニシテ豚ノ急性肺炎(野㗊牛疫) ヨリ分離セルモノナリ本菌ノ まうす二對スル毒力八試䮑閶始前及試驗中再三檢定シタルニ概ネ不變ニシ テ腹腔內注射 =ヨリ 0.001 c.c. (24 時間ぶいよん境養單位) 或八其レ以下

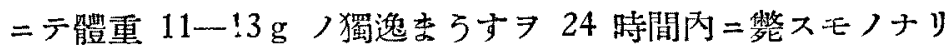

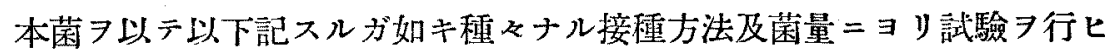
タル

\section{1. 塪胍內注射}

本菌原型てろにー24時間ぶるよん培養 $0.01,0.001,0.0001,0.00001,0.000001$ c.c. /各菌量 7 各一頭/家鬼耳靜 脈內二注射シタル二其紹果八第 1 表ニ示スガ如ク 0.0001 c.c. 7 注射セル一 例 7 除キ他八總テ 24 時間以內ノ經過

第 1 表 强毒菌 (B. 全種) /家琶感染試驗

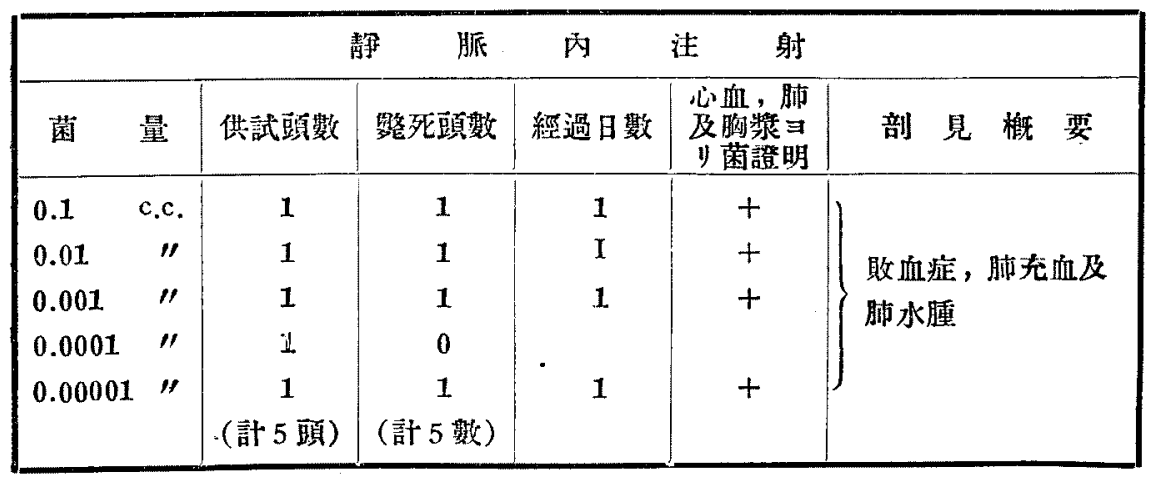




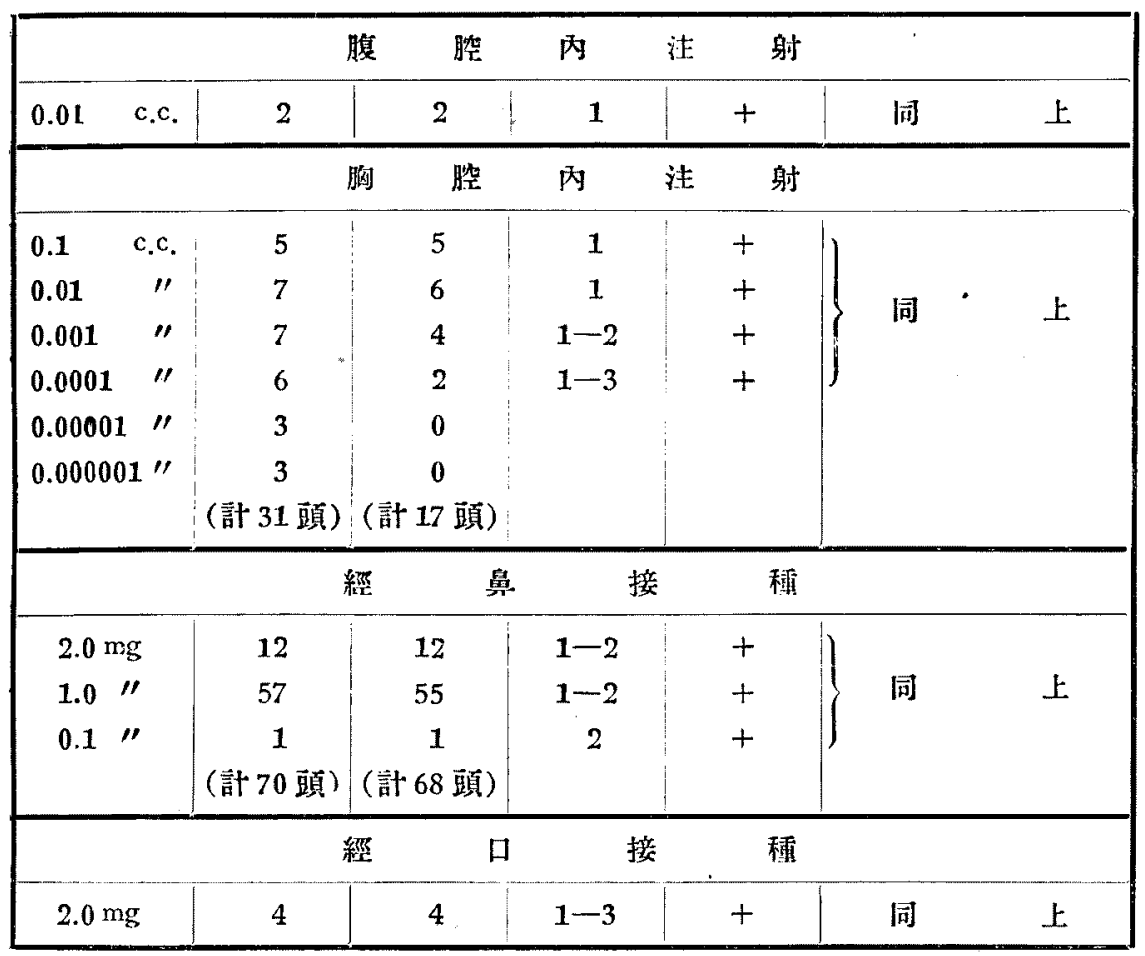

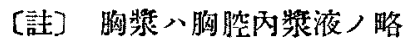

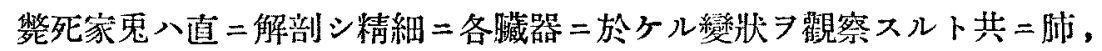
心血，肝，臊，腎及各淋巴腺等ヨリ培養习試ミタルモ、今各例二就テ別個 ニ記載スルノ煩ヨ避ケ概括的二記スレバ各例共何レモ敗血症ニヨリテ愁レ

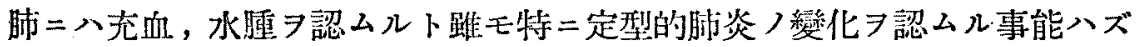
佁菌ハ各䁍器ヨリ登明セラレタリ

\section{2. 腹腔內注射}

前記靜胍內注射 =於ヶルト同一培養 70.01 c.c. 2 頭つ腹腔內二注射シ夕

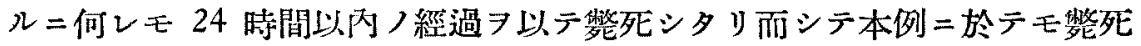
動物ハ何レモ敗血症性變化 7 呈シ肺

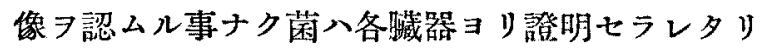

\section{3. 胸腔內注射}

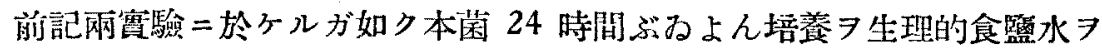


以テ適宜稀椯シ各菌量 7 左側胸腔內 $=$ 注射ヒリ（注射液量八 0.5 c.c. トス） 本試驗八數包反復シタルモ何レモ略同㥞つ成緽ナリシタ以テ第 1 裴二一括 表示シタリ即チ表=示スガ如ク拱試頭數 31 頭ノ內感染獘死シタルモノ 17 頭ニシテ他八何等病狀病變 7 呈セズ而シテ $0.1-0.01$ c.c. 注射セルモノ八殆 F 100\% 感染笅死シ經過八概ホ 24 時間以內ナリシモ以下ノ菌量二於テハ 全部必ズシモ感染セズ又感染整死シタルモノモ其經過八幾分遷延シ 1-3 日ニ百レリ

整死動物入全部剖檢シタルニ一二ノ例外ヨ除キ他入何レモ静脈內腹腔內 注射ニ於ケルガ如キ敗血症性變枵

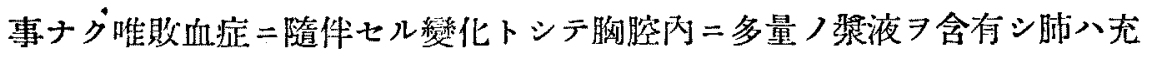
血, 水腫 7 發シ又諸所 $=$ 點狀出血 $尹$ 生ズルモ网眼上朋カ二自然感染例 $=$ 見 ルガ如キ胢炎像

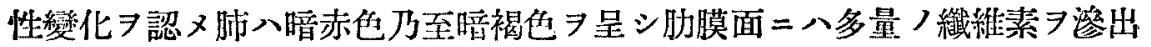
七リ

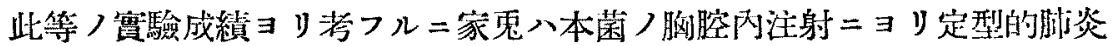
フ發症スルモノナランモ䔈驗上斯ル病例ノ少キハ元來本菌八家鬼二對シテ 病原性强ク從ツテ感染動物八速カ二致死的敗血症＝陷り定型的肺炎成生 暇ナクシテ㢣死スルガ爲ナラン

4. 經鼾感染

以上ノ實驗 $=\Xi$ リ本菌 7 動物體队 $=$ 注射ス儿時八動物八速力二致死的敗

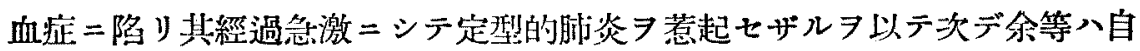
然感染經路 $=$ 準ジタル經鼻經口兩感染試驗

試驗方法八 5\% 馬血液寒天 24 時閒培養菌 7 以テ食監水 $0.05 \mathrm{c} \cdot \mathrm{c}$. 冈二所 要第量 7 含有スルガ如キ菌液 脐醉等ノ前處置ヨナサズ)

實驗八 $2 \mathrm{mg}, 1 \mathrm{mg}, 0.1 \mathrm{mg}$ 及夫次各菌量=就テ反復行ヒタルモ此處

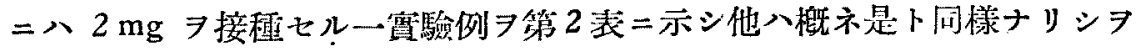
以テ第 1 㤗二一括表示スル事トセリ即チ装ニ示スガ如ク供試家鬼總數 70 
頭ニシテ內感染整死セルモノ 68 頭ナリ更二是 7 各菌量 $=$ 就テ細別スル $2 \mathrm{mg}$ 接種例=於テハ 12 頭全部, $1 \mathrm{mg}$ 接種例=於テハ 57 頭中 55 頭， $0.1 \mathrm{mg}$ 接種例 1 頭中 1 頭ノ感染整死 7 認メタリ $0.1 \mathrm{mg}$ 以下ノ菌量 $=$ 就 テモ試驗 檢並培養試驗 フナシタルニ病變䍃 認メシモノナク又何レノ臟器ヨリモ接種 菌フ證明セザリキ

感染蒙鬼八何レモ $1-2$ 日多クハ2 日ノ經過 =剖檢シ各臟器ニ於ヶル病變ヨ觀察シタルニ總テ大同小異ニシテ敗血症性 變化ヨ示シ前述種ねナル接方法二於ケルト異ナル所ナ゙カリキ唯此場合二於 テハ鼻膑，氣管及氣管忮ノ炎症 ヨ認メシモノ多ク數例二於テハ化膿性咽喉

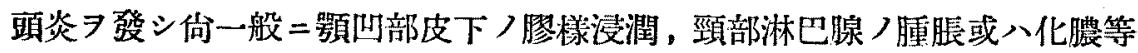
ヨ認メタリ要之經鼻感染二於テモ余等ノ期待=反シ特=肺炎 7 成生スル事 能ハズ他ノ接種方法ニ於ケルト同ジク動物ハ速カ二敗血症ニョリテ斃レ毫 モ定型的昁炎 7 成生七ザリキ

5. 經口感染

次二余等入 4 頭ノ家鬼 $=$ 就 $2 \mathrm{mg} /$ 經口的投與ニヨル感染試驗 タルモ其成䋶八全ク經鼻感染二於ヶルト同樣ナリシタ以テ特ニ試載スル事 ヨ省キ唯其結果ノミ第 1 表二裴示シタリ

6. 菌ノ侵入經路及體內分布

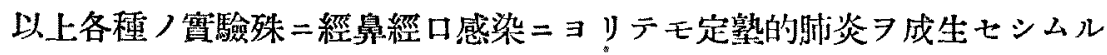
事能ハザリシモ次デ余等二接種菌八一度肺 =達シ其處ヨリ敗血症 =移行 ルモノナリヤ或八接種部 $リ$ 直二血流=入リテ敗血症习惹起スルモノナリ

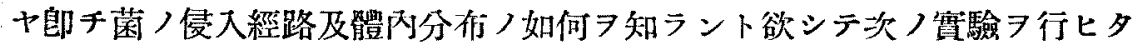
リ

即千豫メ一定數ノ健康家鬼 フ選ピ經鼻感染ニヨル確實ナル致死量 $1.0 \mathrm{mg}$ 7 鼻腔內 $=$ 注大シ $1,3,6,9,12,24,36$ 時間每 $=2$ 頭宛ノ家鬼 7 之一

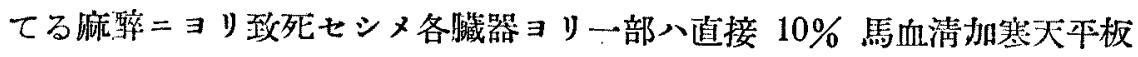
二培養シ殘部八ぶあよん二投ジ 24 時間增菌シタル後更二是 $コ リ$ 血清寒天 


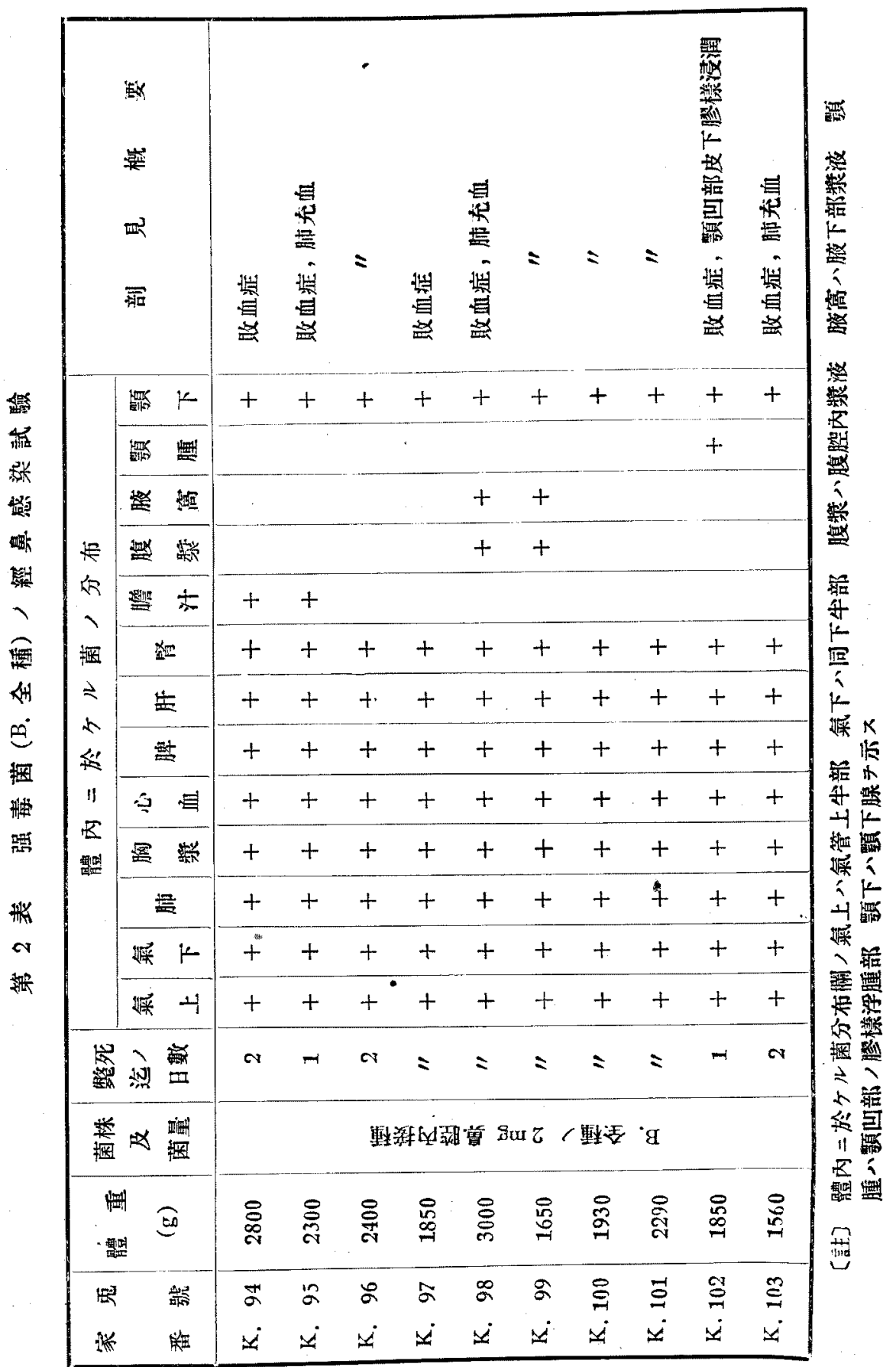




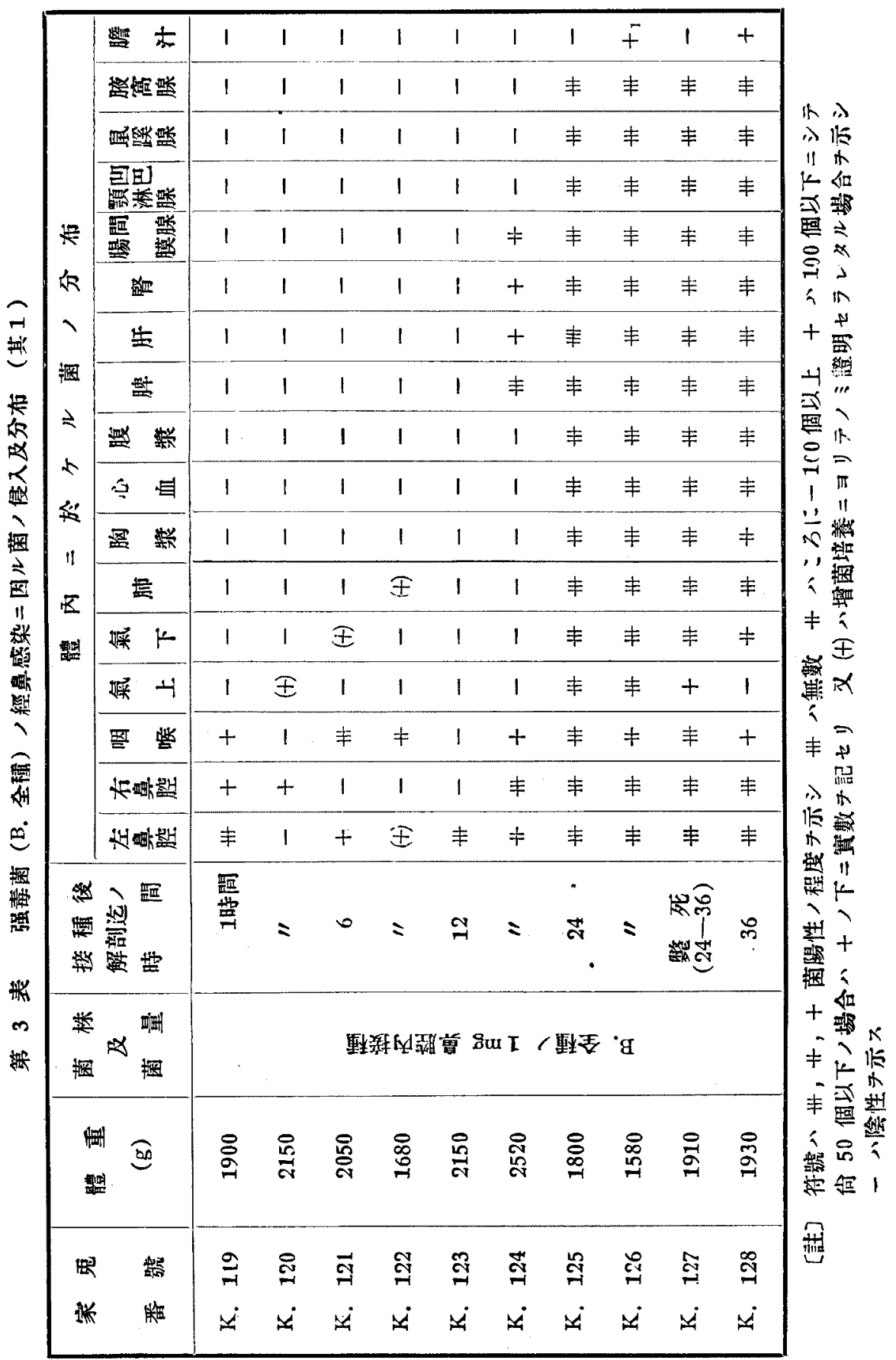




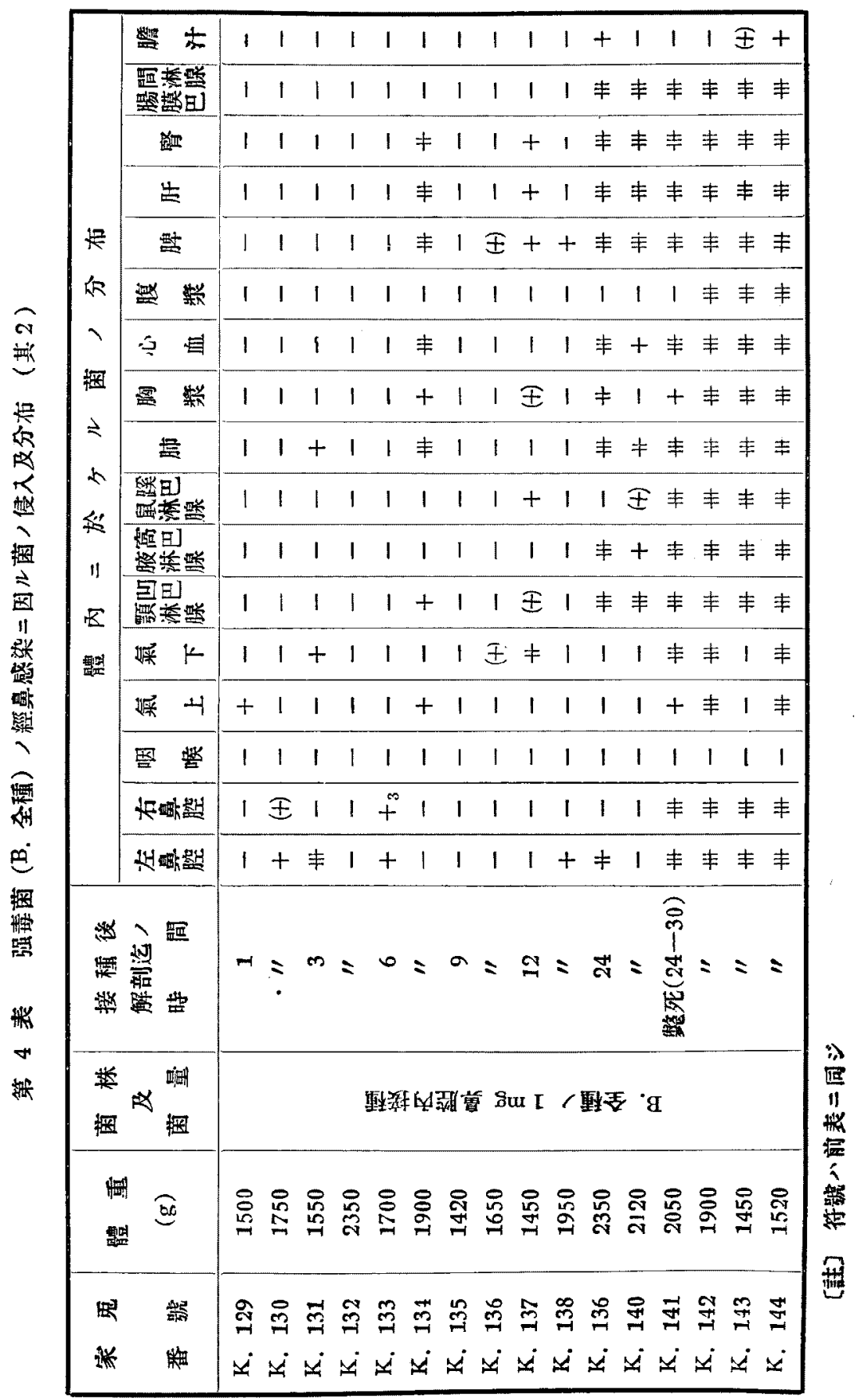




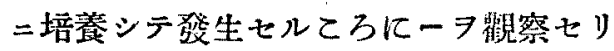

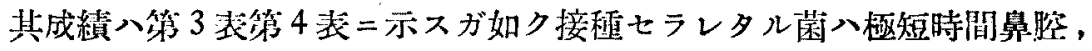

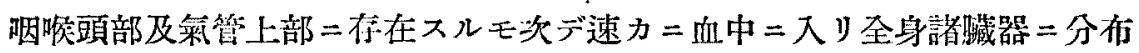
シ此際朋カ二氣道 $コ リ$ 脯 症二移行スルガ如キ事實八認メラレザリキ，即本菌ノ家鬼二於ケルガ如ク 病原性强キ菌種 $/$ 感染二於テハ極短時間队二接種部位 $ヨ$ リ直二血中二入リ 此處二發育增殖シテ圶身諸臟器=分布スルニ至ルモノニシテ經鼻䋔口等 自然感染經路 $=\exists$ ル場合八上部氣道粘膜 $ヨ リ$ 道 $=$ 血流 $=$ スリ敗血症 $\exists$ 惹起 スルモノナリ而シテ肺

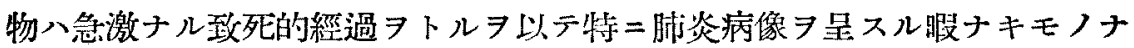
ル可シ師チ病原性强キニ失スル菌橥 =敗血症死 7 來ス 7 以テ定型的划炎 7 成生セシムルコト能ハザルモノ如シ

B. 强毒菌種 (L. 一部及同種蔺) ヨ以テセル場合

本試驗 $=$ 月ヒタル菌株八蒙免敗血症ヨリ分離セラレタル出血性敗血症菌 シシテ本菌ノ性狀並分類等二就テハ别途報告スル豫定ナル 以テ此庭二八 之ヨ省略ス本菌ノまうす二龂スル毒力八前述 B. 全種二略々同ジキモ多少 搦ク經過幾分僊延スルモノナリ

\section{1. 胸腔內注射}

B. 全種胸腔內注射二於ヶルト全ク同一ノ手技ニヨリ L. 一部ノ 24 時間 ぶわよん培盖 $0.1,0.01,0.001,0.0001,0.00001,0.000001$ c.c. 7各一頭ノ 家兔二注射シタル二第 5 表二示スが如キ成績 $尹$ 得タリ

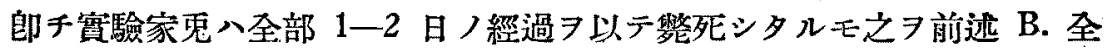
種つ同一實驗=比較スルニ幾分長ク B. 全種二於テハ多クハ 24 時間以內 二整死シタルモ本菌ノ場合二於テハ36-48 時間內处 =及べ整死家鬼八 精細二剖檢シタルニ何レモ胸腔內二溷濁セル稳液ヨ多量 $=$ 含有シ肋膜八肥 厚シ且繊維素樣ノ膿フ多量附着セリ脯入暗赤色乃至暗褐色ニシテ主トシテ 左葉前牛部 $=$ 肝變樣變化 7 示シ闪眼上明カ二大葉性繊維素性肋膜脑炎 7 呈 シ此變化ハ主トシテ接種倒二著シキモ又必ズシモ然ラザリキ斯ル胸腔內二 
第 5 表 强毒菌 (L, 一部) 八胸䐑內注射感染試驗

\begin{tabular}{|c|c|c|c|c|c|c|c|}
\hline \multirow{2}{*}{$\begin{array}{l}\text { 家 霆 } \\
\text { 番 號 }\end{array}$} & \multirow{2}{*}{$\begin{array}{c}\text { 體 重 } \\
(\mathrm{g})\end{array}$} & \multirow{2}{*}{$\frac{\text { (c.c. })^{\text {量 }}}{}$} & \multirow{2}{*}{$\begin{array}{l}\text { 䌘 } \\
\text { 迄 } \\
\text { 日 }\end{array}$} & \multicolumn{3}{|c|}{ 培 蕵 所 見 } & \multirow{2}{*}{ 剖見概 要 } \\
\hline & & & & 心 血 & 肺 & 胸 獎 & \\
\hline K. 344 & 2480 & 0.1 & 2 & + & + & + & 定型的肺咨 \\
\hline K. 345 & 3050 & 0.01 & $\prime \prime$ & + & + & + & $" \prime$ \\
\hline K. 346 & 2370 & 0.001 & $" \prime$ & + & + & + & $"$ \\
\hline K. 347 & 2400 & 0.0001 & $" \prime$ & + & + & + & $" \prime$ \\
\hline K. 348 & 3060 & 0.00001 & 1 & + & + & + & " \\
\hline K. 349 & 2660 & 0.000001 & $" \prime$ & + & + & + & " \\
\hline
\end{tabular}

於ヶル病變以外一般諸臟器 $=$ 於テハ明カニ出血性敗血症變化 ノ病變八自然發生＝於ヶルB型菌＝因ル牛豚つ病變及本菌＝因ル芜鬼肺炎 二酷似セリ郎チ本菌 7 家鬼胸腔內 =注射スレバ明カ =急性大葉性肺炎 7 發 シ次デ速カ二敗血症=陷リ動物八是ガ䳕二整死スルモノ、如シ份接種菌八 各臓器ヨリ證明セラレタリ

\section{2. 經鼻感染}

本菌及本菌卜同種菌二シテ同一流行洔ニ於ケル蒙克敗血症 $コ$ 分離セル L. 一部 9 號，L. 一部 10 號，L. 細 5, L. 細 14, L. 細 17, L. 細 29 ノ各菌種 $尹$ 以テ $1.0 \mathrm{mg}$ 經鼻感染 7 行ヒタル成績八第 6 表=示スガ如シ

師チ表ニヨリテ明カナル如ク此等ノ菌種ヨ以テセル經鼻感染二於テハ前 述全B.全種二同ジク多クハ感染シ結果トシテ敗血症死 7 來スモ其經過八概 ネ遷延シ 2-I0 日二亘リ而シテ剖檢變狀入全部必ズシモ整一ニ非ズシテ20 例中 6 例八前記胸腔內 注射 =於ヶルト全ク同樣ナル定型的大葉性肺炎像 ヨ呈シタルモ他入大葉性肺炎ノ所見 血等ヨ發シタルニ過ギザリキ而シテ此等ノ動物ニフリテハ多ク八顎凹部皮 下ノ膠樣浸㵎，頸部淋巴腺ノ化膿性炎症等アリ惟フ二斯儿場合=於テハ菌 八咽呢頭部二於テ發育增殖シ氣道ヲ介シテ直二肺ニ大ルコトナク該部ョリ 直 =血流ニ入リテ敗血症ヨ惹起シタルモノナル可シ份整死動物入何レノ場 合 $=$ 於テモ敗血症死ヨ來シ從ツテ菌ハ各臟器ヨリ登明セラレタリ 
第 6 表强毒菌 (L。一部及同種菌)，經鼻感染試驗

\begin{tabular}{|c|c|c|c|c|c|c|c|c|c|c|c|}
\hline \multirow{2}{*}{$\begin{array}{l}\text { 家 } \\
\text { 番 }\end{array}$} & \multirow{2}{*}{$\begin{array}{l}\text { 坖 } \\
\text { 號 }\end{array}$} & \multirow{2}{*}{$\begin{array}{l}\text { 體 }{ }^{\text {重 }} \\
(g)\end{array}$} & \multirow[b]{2}{*}{ 菌 } & \multirow[b]{2}{*}{ 株 } & \multirow{2}{*}{$\begin{array}{c}\text { 菌 量 } \\
(\mathrm{mg})\end{array}$} & \multicolumn{2}{|c|}{ 獘死迄 } & \multicolumn{3}{|c|}{ 境 養 所 見 } & \multirow[b]{2}{*}{ 剖 } \\
\hline & & & & & & & 數 & $\begin{array}{c}\text { 心 } \\
\text { 血 }\end{array}$ & 肺 & $\begin{array}{l}\text { 胸 } \\
\text { 䠌 }\end{array}$ & \\
\hline$k$. & 373 & 1800 & L. $\rightarrow$ & 部 & 1 & 6 & & + & + & + & 敗血症 \\
\hline $\mathrm{k}$. & 374 & 1840 & $" \prime$ & & $" \prime$ & 7 & & + & + & + & 敗血症, 腹膜笑, 腸間膜腺, 化膿 \\
\hline $\mathrm{K}$, & 375 & 2100 & $\prime \prime$ & & $" \prime$ & $" \prime$ & & - & - & - & 著變ナシ \\
\hline $\mathrm{K}$. & 376 & 2010 & $"$ & & $\prime \prime$ & " & & + & + & + & 定型的肺筷 \\
\hline K. & 377 & 1700 & $\prime \prime$ & & " & (21日生 & 存 & - & - & - & 著檚ナシ \\
\hline 對 & 19 & 1520 & $"$ & & $" \prime$ & 10 & & - & - & + & 左肺前葉 =出血部アル外著變ナシ \\
\hline$" \prime$ & 20 & 2450 & " & & $"$ & 3 & & + & + & + & $\begin{array}{l}\text { 肺充血, 肋膜下點狀出血，下腹部皮 } \\
\text { 下膠榡浸潤 }\end{array}$ \\
\hline$"$ & 24 & 2250 & $" \prime$ & & $"$ & $" \prime$ & & + & + & + & 定型的肺笑 \\
\hline K. & 415 & 1550 & L.一部 9 & & $\prime \prime$ & 5 & & + & + & + & $" \prime$ \\
\hline $\mathrm{K}$ & 416 & 1650 & $\prime \prime$ & & " & 生 & 存 & & & & \\
\hline $\mathrm{K}$. & 417 & 1750 & L.一部10 & & " & 44 & & + & + & + & 肺治血及水腫 \\
\hline $\mathrm{K}$. & 418 & 1550 & $\prime \prime$ & & $"$ & 6 & & + & + & + & 敗血症, 腹膜咨 \\
\hline $\mathrm{K}$. & 419 & " & L. 細 & & " & 2 & & + & + & + & 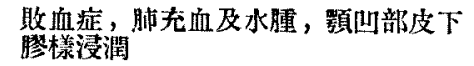 \\
\hline $\mathrm{k}$. & 420 & " & " & & $" \prime$ & $\prime \prime$ & & + & + & + & 定型的脯奜 \\
\hline K. & 421 & 1500 & L. 細 I & 14 & $\prime \prime$ & 6 & & + & + & + & $\prime \prime$ \\
\hline $\mathrm{k}$, & 422 & 1400 & $\prime \prime$ & & " & 10 & & + & + & + & 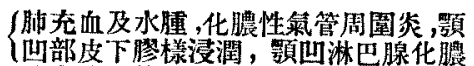 \\
\hline $\mathrm{k}$. & 423 & " & L， 細 J & 17 & " & 4 & & + & + & + & 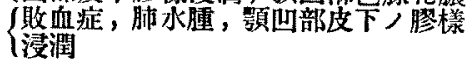 \\
\hline $\mathrm{K}$. & 424 & $\prime \prime$ & $\prime \prime$ & & " & 2 & & + & + & + & 敗血炡, 肺充血 \\
\hline $\mathrm{K}$. & 425 & 1750 & L。絧 & 29 & $"$ & 3 & & + & + & + & 定型的肺悠 \\
\hline K. & 426 & 1700 & $\prime \prime$ & & " & "' & & + & + & + & 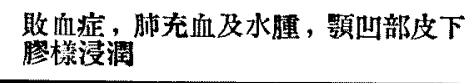 \\
\hline
\end{tabular}




\section{3. 菌 /侵入及體內分布}

前記 B. 全種ノ場合卜全ク同様ナル方法ニヨリ菌ノ侵入及體內分析フ試 驗シタル $=$ 其成繢入第 7 表二示スガ如シ而シテ本菌ノ場合八全ク B. 全種 ノ場合ト同樣ナルラ以テ特二說明 7 要セズ唯 B. 全種ニ比シ經過幾分長キ 尹以テ定型的肺炎 7 惹起スル昵了ル點二於テ相異スルノミ

以上ノ實驗成績二示スガ如ク本菌ノ芜忽二於ヶルガ如ク菌對動物ノ關係 ガ肺炎發生二丁度適當ナルモノ =アリテハ實驗的 $=$ 容易 $=$ 定型的大葉性肺 炎习成生セシメ得ルモノナリ而シテ其方法八胸腔內注射 $=ヨ$ ル場合最モ確 實ニシテ經鼻經口感染八必ズシモ確實ナラズ其ノ故八後者つ場合接種菌八 必ズシモ氣道习介シテ肺 リ直二敗血症二移行シ得ル場合アルヨ以テナル可シ

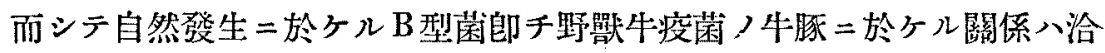
モ本菌ノ家鬼ニ於ヶル關係二最モ近似セルモノナリト思考七ラル

C. 弱毒菌種 (S. 汇原) ヨ以テセル場合

本試驗二用ヒタル S. 汇原八出血性敗血症菌屬中ノ越智ノ所詡 C 型菌株 ニシテ豚ノ肺炎 (所詡豚设) ヨリ分離セルモノナリ本菌八分離後約 1 ケ年 培養保存セラレタルモノニシテ試驗當時二於ケルまうす二對スル毒力八ぶ い上ん培養 0.00001 c.c. 腹腔內注射ニョリテ9日ニ之ヨ整ス程度ナリキ

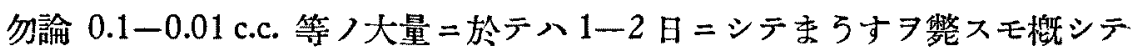
其經過長ク前述兩菌種=比スレバ明カニ毒力弱キモノナリ

1. 經鼻感染

本菌 7 家鬼ノ皮下, 腹腔, 靜脈內等二大量接種 7 行へバ動物ハ一次性敗 血症 ナル處ナク肺モ亦特株ノ病像 $ᄏ$ 呈スルコトナク單二充血水腫 7 生ズル程度 ナリキ

依テ余等ハ本菌血液寒天培養 $2 \mathrm{mg} 7 \mathrm{~B}$ 型菌接種ニ於ヶルト同樣ノ方法 ニヨリ經鼻感染セシメタル＝動物八長ク生存シ特殊ノ病狀 $フ$ 程スルコトナ カリキ郎チ本菌八經鼻感染ニヨリテハ家鬼 


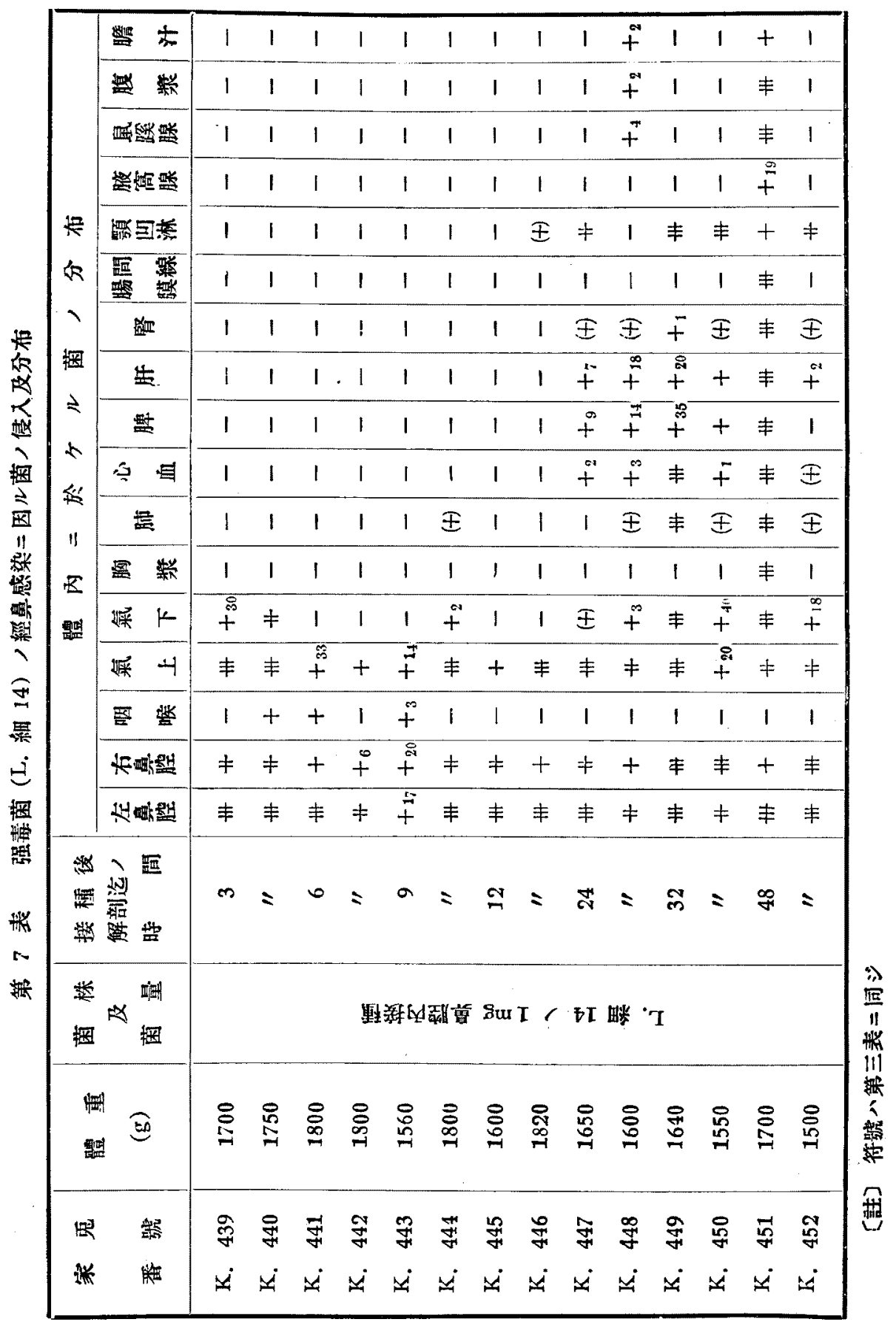


知レり

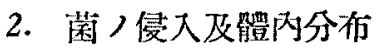

前記ノ翼驗ヨリ本菌ノ經鼻感染ニヨリテハ芜鬼 7 發症七シムル事困難ナ ルヨ知リタルモ然ラバ接種菌八芜象體內二於テ如何ナル遇命二陷ルモノナ

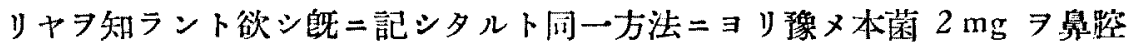

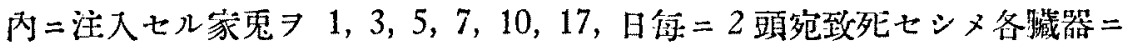

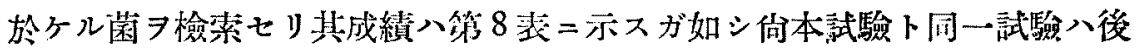
述免疫試驗つ對照二於テモ行七其成䋶八第 15 表二示セリ

此等”成䋶

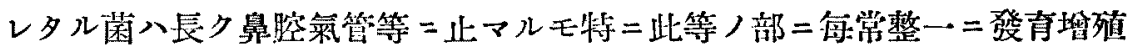

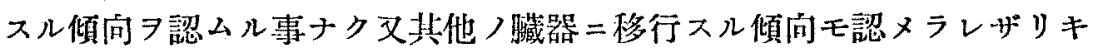

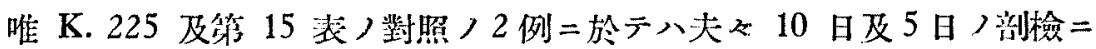

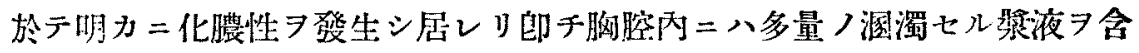

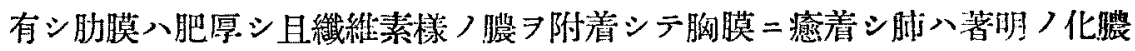
性炎症 ヨ發シ菌八肺，心血，氣管等二證明七ラレタリ的千此 2 例二於テハ 接程セランタル菌ハ氣道ヨリ肺 ノ化跀性肺炎 7 發シ次デ敗血症二移行セントスル狀態ニアリシモノト認定 ス可ク洽モ自然發生二於ヶル所謂慢性豚疾二游彿夕リ

要之本菌ノ芜鬼感染二於ケルガ如ク菌打弱キモノニ於テハ經鼻感染七シ メレル菌ハ上部氣道粘腹ヨリ直二血流ニ入リ敗血症 コトナク(菌八血行ニ入ルモ直二減殺セラル、モノナラン)卑膑, 咽㩔頭,

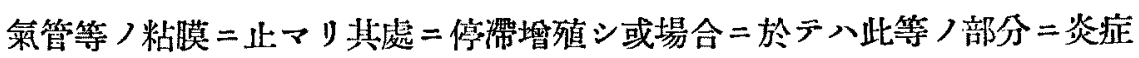

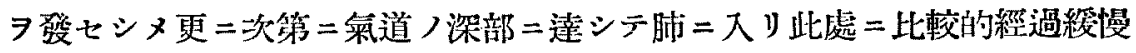
ナル加答兒性化膿性肺炎习發生七シムルコトアル可キモ是レーツニ動物ト 菌卜ノ相互關係ニヨリテ左右七ラレ或場合二八郋症七シメ或場合二八發症 セシメザルモノナル可シ從ツテ本菌ノ如キ菌力弱キ菌種 性肺炎ヨ成生セシムル可能性アルモ每常確惯二發症セシムルコトハ甚ダ困 難ナリ 


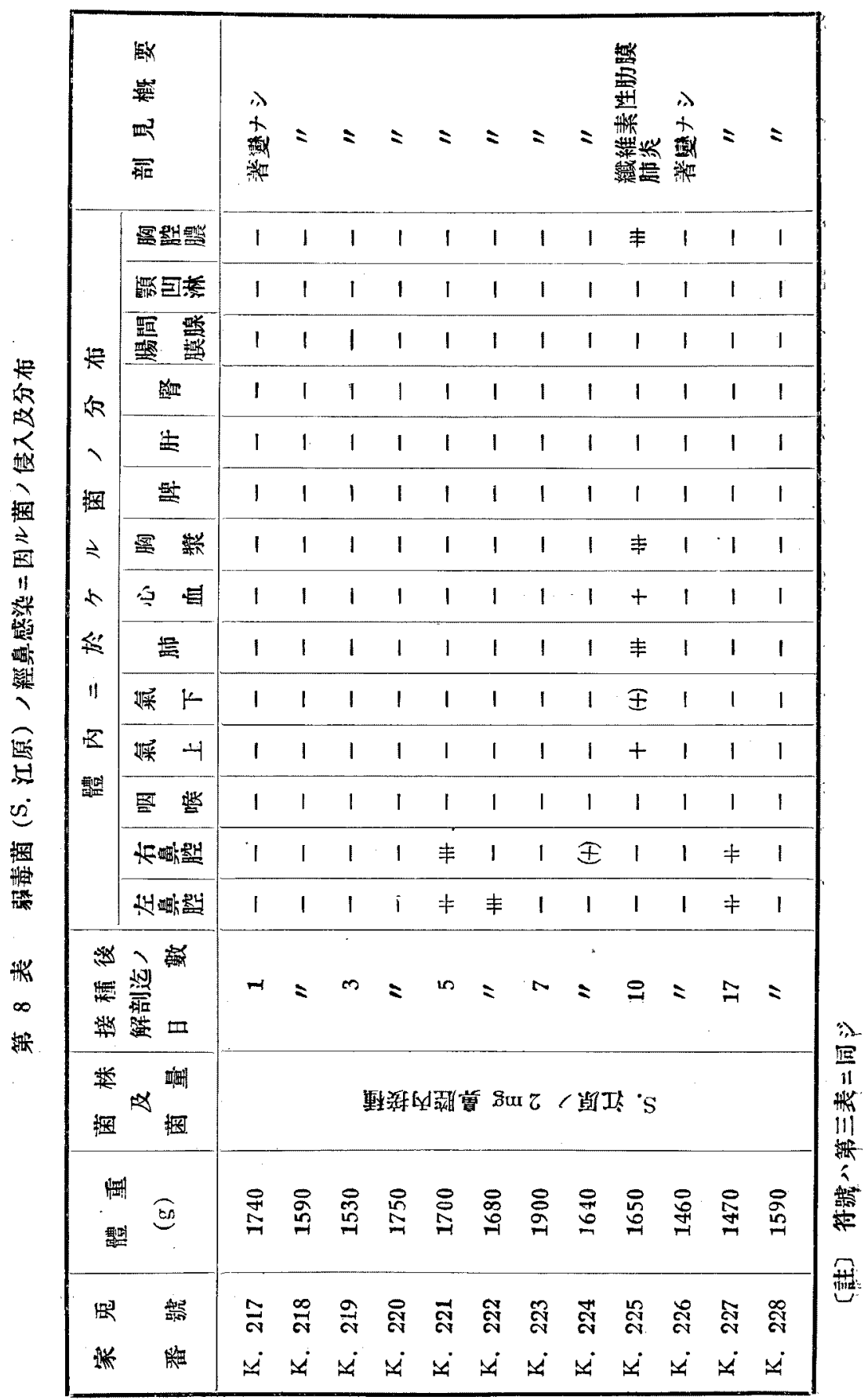




\section{D. 弱装菌禹 (Bact. bronchisepticus) ヨ以テセル場合}

本試驗二使用七儿菌株 Br. III 八健康家鬼 $コ$ 分離七ルモノナリ元來 Bact. bronchisepticus 八健康ナル犬, 家鬼, 海猽等〉上部呼吸器粘膜=存

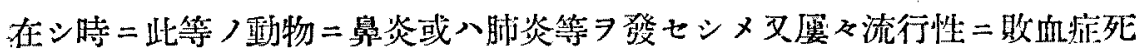

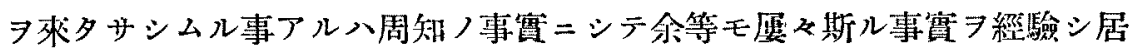
ע

從ツテ本菌ヨ以テスル家鬼實驗八試驗前充分本菌保有二就テ考慮スルニ 非ザレバ其成續二誤 7 來ス可シ余等八此點＝鑑ミ豫メ試驗前再三佔試動物 ノ鼻孔，咽喉頭ノ檢植习行ヒ本菌保有ナキモノノミヨ使用シタリ

\section{1. 胸腔队注射}

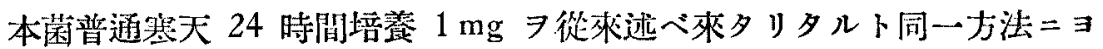
リ胸腔內二法射シタル

師千表二明カナルガ如ク實驗頭數 15 頭中 2 頭 $(\mathrm{Kb} .14, \mathrm{~Kb} .13$ ) 八夫 々 2 日及 5 日目二感染斃死シタルモ其他ノモノ八何等病狀ノ認么可キモノ ナキフ以テ表示ノ如キ日數二於テ順次殺シ剖檢スルト共二各部諸䋗器 $コ$ 培養試驗 7 行ヒタリ其結果八 Kb. 6 八 8 日目 $=$ 殺シタル際 $=$ 肺 $=$ 化胀性 纖維性肋肺炎

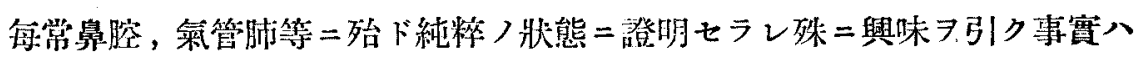
胸腔內 =接種セラレタル菌ハ單二接種部位=止マルノミナラズ上行性:上. 部㴋道粘膜二洋シ其部二發育增殖セル事ナリ

\section{2. 經鼻感染}

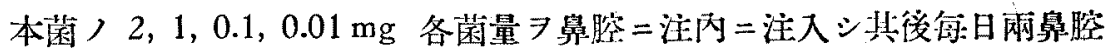

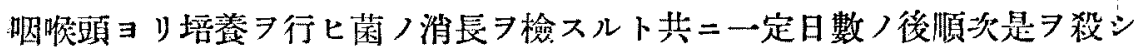
剖檢培䓹

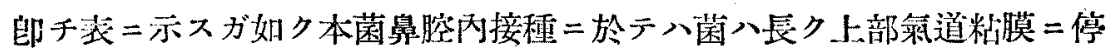

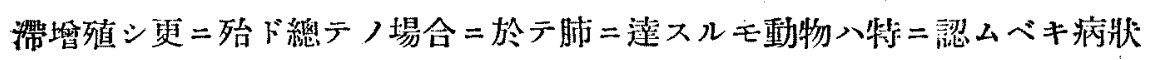
䠔變习呈セザリキ

以上二ツノ蕒驗成績ニヨリテ知ラル事惯入本菌ノ家兔ニ於ケルガ如り菌 


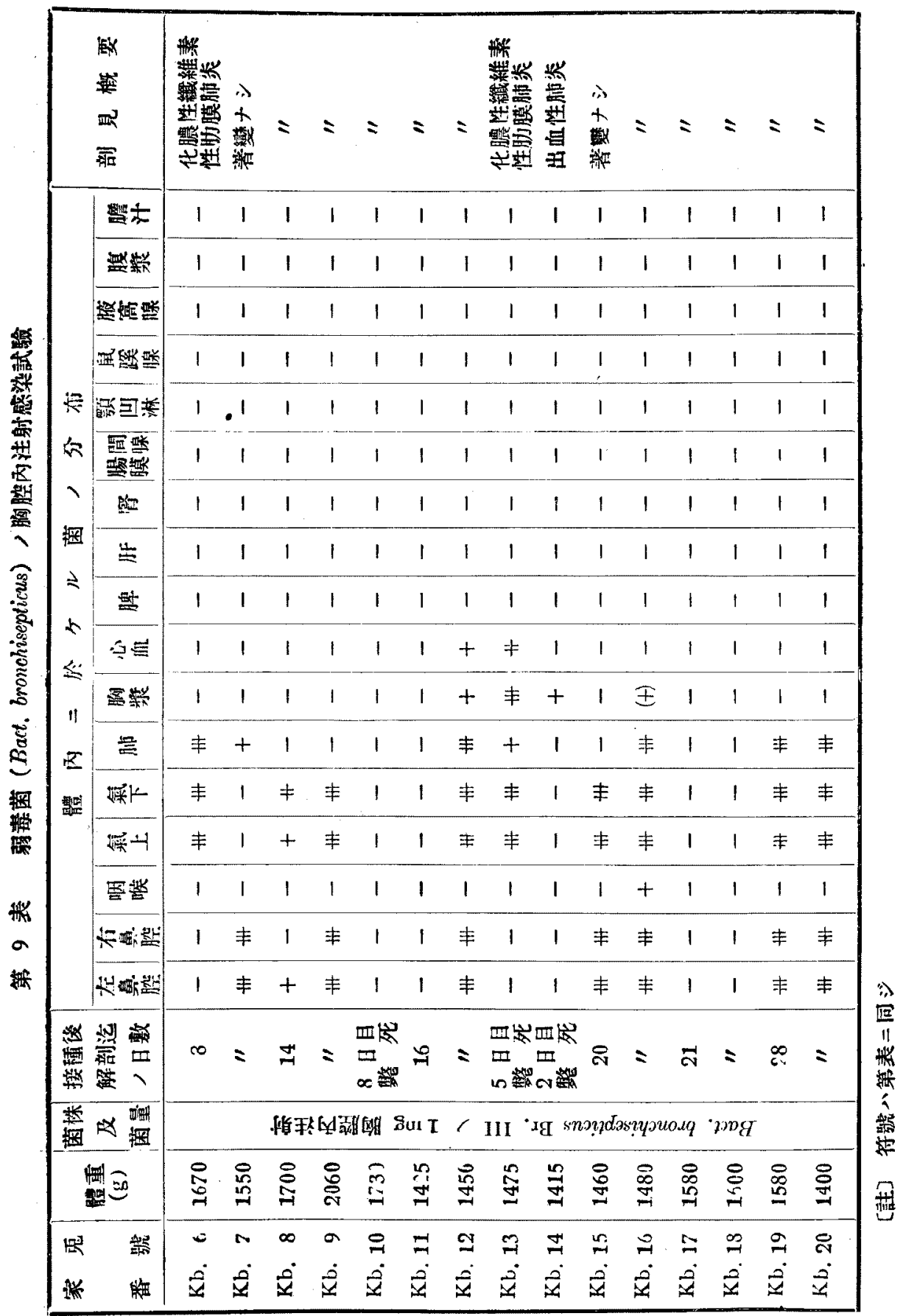


第 10 表哥毒菌 (Bact. bronch!septicus)，經悬感染二因ル菌，侵入及分布

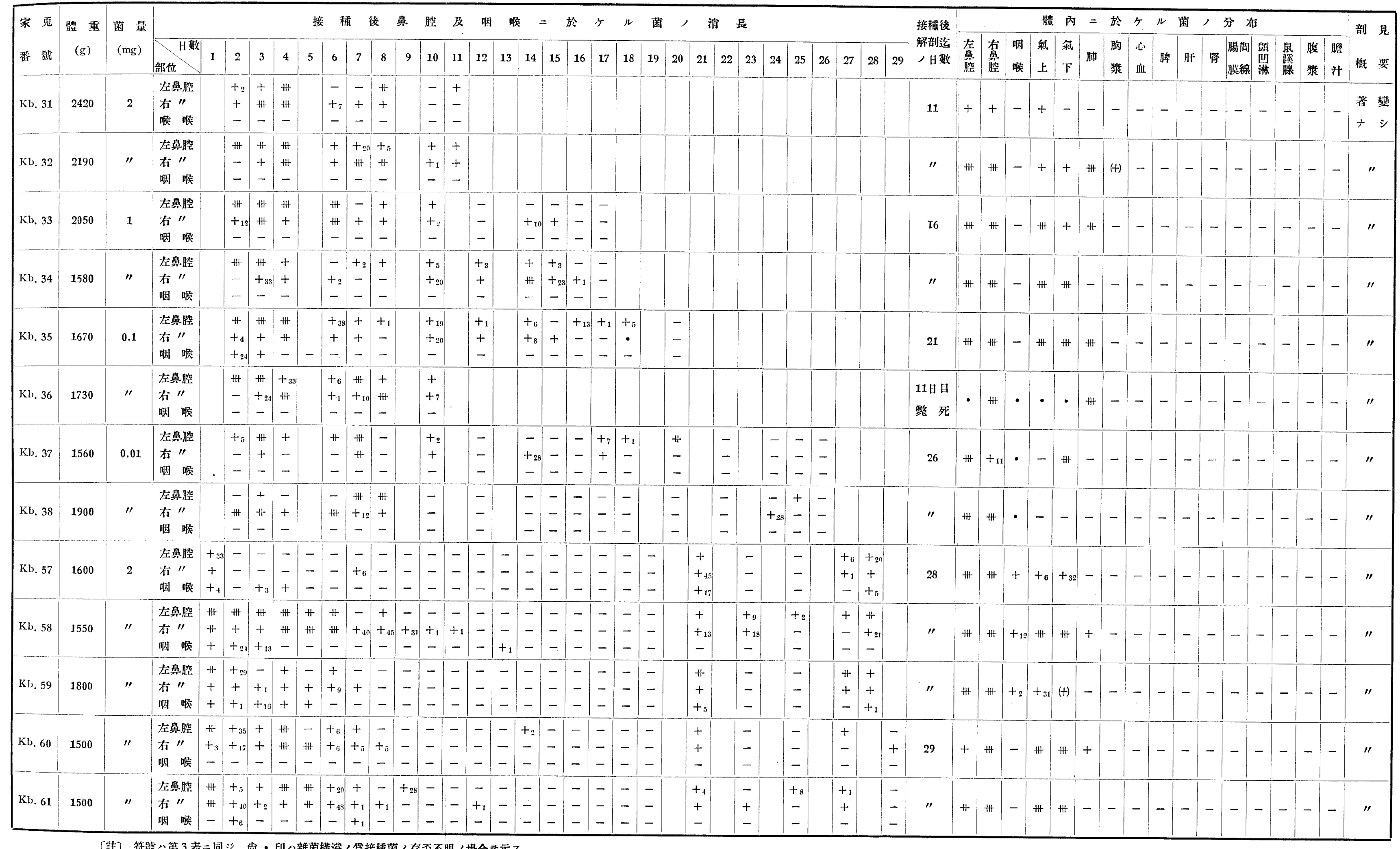

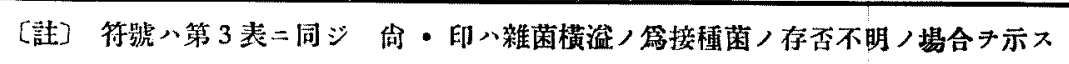


カ弱キモノニ於テ接種セラレタル菌八長ク呼吸器粘膜ニ止マリ其處 =一程 度發育スルモ多クノ場合肺炎或八上部氣道ノ炎症习起サ、゙ル事ナリ乍然斯 クノ如ク菌ノ氣道二存在發育スルモノナル ルカ或八余等ノ胸腔內注射 (大量) =認メタルガ如キ場合二遭遇スレバ特 殊ノ肺炎性疾患或八上部氣道ノ炎症ヨ發スルモノナラン

\section{II. 肺炎ノ免疫二關スル試驗}

前章=記载シタルガ如ク種ふナル菌種＝因ル種タナル病型郎チ急性敗血 症 $=$ 隨伴ス几䀯充血 (B. 全種ノ如生場合)，一次性大葉性肺炎 $\exists$ 直二敗 血症二移行スルモ（L. 一部ノ如キ場合), 主トシテ氣道二菌ガ存在シ時 二限局性化膿性肺炎ヲ發生スルモ（S. 江原及 Br.III ノ如キ場合）等= 就テ實驗シ略々其ノめがにずむヨ察知シ得タレバ次で余等八此等ノ各場合 ノ免疫二就テ嘪驗

實驗方法

供試家鬼入總テ前記發生試䮦ニ於ケルト同樣ノモノョ同一ノ注意ノ下ニ 用ヒタリ

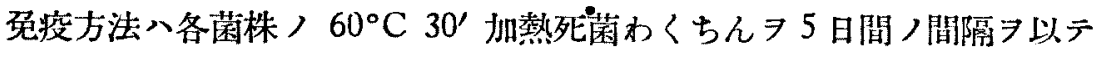
3 回（第 I 回 $1 \mathrm{mg}$ ，第 II 回 $2 \mathrm{mg}$, 第 III 回 $5 \mathrm{mg}$ ) 皮下或八䋛脈內= 注射スル方法ヨ取レリ感染八免疫注射完了後 10 日ヨ經テ主トシテ經鼻的 ニ行ヒタルモ又胸腔內注射

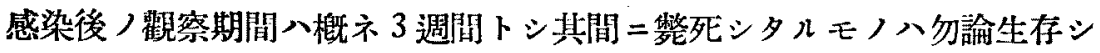

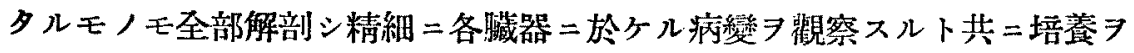
行ヒ接㮔菌ノ存否 檢シタリ其他ノ點二就テ八前章㢱生試驗ニ行ヒタルト 同一ナレバ省略ス可シ

A. 强毒菌種 (B. 全種) 感染 $=$ 對スル免疫

先ッ゙强毒菌 B. 全種死菌わくちん皮下注射 $=\exists$ 㣻疫家兔 19 嘼=同名 菌ノ胸腔內及經鼻感染 $フ$ 行ヒタル

此成續＝低レバ對照動物ハ總テ前章感染試驗＝記载シタルト全ク同樣， 
第 11 表 强毒菌 (B. 全種) 二對スル同名菌死菌免疫試铪

\begin{tabular}{|c|c|c|c|c|c|c|c|c|c|c|}
\hline \multirow{2}{*}{$\begin{array}{l}\text { 家 西 } \\
\text { 蕃 號 }\end{array}$} & \multirow{2}{*}{ 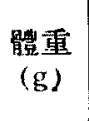 } & \multirow{2}{*}{$\begin{array}{l}\text { 免 疫 } \\
\text { 菌 } \\
\text { 及方法 }\end{array}$} & \multicolumn{3}{|c|}{ 喣染菌株及方法 } & \multirow{2}{*}{ 結果 } & \multicolumn{3}{|c|}{ 培 養 所 見 } & \multirow{2}{*}{$\begin{array}{c}\text { 生存率 } \\
(\%)\end{array}$} \\
\hline & & & 菌株 & 菌量 & 部位 & & 心血 & 肺 & 胸繁 & \\
\hline K. 145 & 1785 & \multirow{19}{*}{ 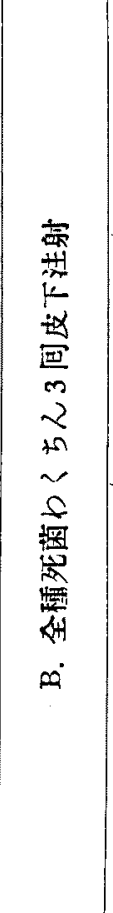 } & \multirow{5}{*}{ siti } & \multirow{5}{*}{$\begin{array}{l}\dot{0} \\
\dot{0} \\
\ddot{0}\end{array}$} & \multirow{5}{*}{ 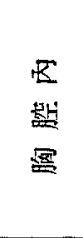 } & 死 $_{1}$ & + & + & + & \multirow{5}{*}{0} \\
\hline K. 145 & 1415 & & & & & 死 & + & + & + & \\
\hline K. 147 & i565 & & & & & 死 & + & + & + & \\
\hline K. 148 & 1465 & & & & & 死 & + & + & + & \\
\hline K. 149 & 1750 & & & & & 死 $_{1}$ & $\dot{+}$ & + & + & \\
\hline K. 150 & 1575 & & \multirow{5}{*}{ " } & \multirow{5}{*}{$\begin{array}{l}\dot{0} \\
\dot{0} \\
0 \\
0 \\
0\end{array}$} & \multirow{5}{*}{$" 1$} & 死 & + & + & + & \multirow{5}{*}{0} \\
\hline K. 151 & 1665 & & & & & 死 & + & + & + & \\
\hline K. 152 & 1765 & & & & & 死 $_{1}$ & + & + & + & \\
\hline K. 153 & 1925 & & & & & 死 & + & + & + & \\
\hline K. 154 & 1605 & & & & & 死 & + & + & + & \\
\hline K. 155 & 1590 & & \multirow{9}{*}{$\prime \prime$} & \multirow{9}{*}{$\begin{array}{l}\stackrel{b}{E} \\
-1\end{array}$} & \multirow{9}{*}{ 폼 } & 生 & \multirow{9}{*}{$\begin{array}{l}+ \\
+\end{array}$} & \multirow{9}{*}{$\begin{array}{l}+ \\
+\end{array}$} & \multirow{9}{*}{$\begin{array}{l}+ \\
+\end{array}$} & \multirow{9}{*}{70} \\
\hline K. 156 & 1460 & & & & & 生 & & & & \\
\hline K. 157 & 1950 & & & & & 生 & & & & \\
\hline K. 158 & 2000 & & & & & 死 ${ }_{3}$ & & & & \\
\hline K. 159 & 1550 & & & & & 死 2 & & & & \\
\hline K. 160 & 1450 & & & & & 生 & & & & \\
\hline K. 161 & 1505 & & & & & 死 & & & & \\
\hline K. 162 & 1460 & & & & & 生 & & & & \\
\hline K. 163 & 1940 & & & & & 生 & & & & \\
\hline 對 I & 1475 & & " & \multirow{2}{*}{$\stackrel{5}{E}$} & \multirow[t]{2}{*}{$" \prime$} & 死 & + & + & + & \multirow{2}{*}{0} \\
\hline$\prime \prime$ II & 1875 & & & & & 死: & + & + & + & \\
\hline$\prime \prime$ III & 1540 & & \multirow[t]{2}{*}{ " } & \multirow{2}{*}{$\begin{array}{l}\dot{0} \\
\dot{0} \\
-1 \\
0\end{array}$} & \multirow{2}{*}{$\begin{array}{c}\text { 胸 } \\
\text { 肤肉 } \\
\end{array}$} & 死 & + & + & + & \\
\hline "I IV & 1575 & & & & & 死 $_{1}$ & + & + & + & 0 \\
\hline$\prime \prime \quad \mathrm{V}$ & 1620 & & $"$ & $\dot{ن}$ & 11 & 死 & + & + & + & \\
\hline$\prime \prime \quad \mathrm{V}$ & 1460 & & & $\stackrel{0}{0}$ & & 死 $_{1}$ & + & + & + & 0 \\
\hline
\end{tabular}

[註] 對卜心對照動物ノ喜 結果ノ闌ノ「死」ノ下ノ數字心整死迄ノ日數 キ示入

經過及症状 7 以テ獘死シ又免疼動物 =於テモ $0.1-0.01$ c.c. ノ如キ大量菌 7 胸腔內注射セシモノハ對照ト全ク同一二感染敝死シタルモ $1 \mathrm{mg}$ 經鼻感染 ヨ行ヒタルモノハ9 䫒中 3 頭ノミ對照=比シ稍く後レテ整死シ他ハ健存 
七り

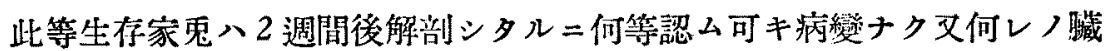
器ヨリモ接種菌 7 證明スルコトナカリキ此成績 $=$ 鑑ミ次 $=18$ 頭ノ家鬼二

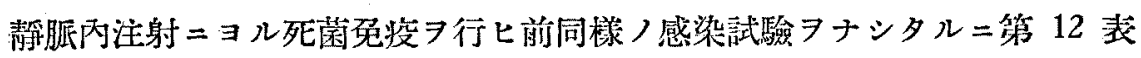

第 12 㤗 强毒菌 (B. 全種) 二對スル同名菌死菌免疫試驗

\begin{tabular}{|c|c|c|c|c|c|c|c|c|c|c|}
\hline \multirow{2}{*}{$\begin{array}{l}\text { 家 鬼 } \\
\text { 番 㩆 }\end{array}$} & \multirow{2}{*}{ 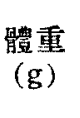 } & \multirow{2}{*}{$\begin{array}{l}\text { 免 疫 } \\
\text { 菌株 } \\
\text { 方法 }\end{array}$} & \multicolumn{3}{|c|}{ 感染菌株及力法 } & \multirow{2}{*}{ 結果 } & \multicolumn{3}{|c|}{ 培 養 所 見 } & \multirow{2}{*}{$\begin{array}{c}\text { 生存㲞 } \\
(\%)\end{array}$} \\
\hline & & & 菌憡 & 菌量 & 部位 & & 心血 & 㬨 & 胸漿 & \\
\hline K. 172 & 1720 & & & & & 生 & & & & \\
\hline \multirow{2}{*}{$\begin{array}{l}\text { K. } 173 \\
\text { K. } 174\end{array}$} & 1760 & & . & & & 生 & & & & \\
\hline & 1700 & & & & & 生 & & & & \\
\hline K. 175 & 1500 & & & & & 生 & & & & \\
\hline K. 176 & 1660 & 察 & 4 & bo & $x$ & 生 & & & & 90 \\
\hline \multirow{2}{*}{$\begin{array}{l}\text { K. } 177 \\
\text { K. } 178\end{array}$} & 1890 & $\frac{H}{2}$ & $x^{2}$ & 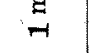 & ming & 生 & & & & \\
\hline & 1500 & 當 & & & & 生 & & & & \\
\hline \multirow{2}{*}{$\begin{array}{l}\text { K. } 179 \\
\text { K. } 180\end{array}$} & 1990 & 綂 & & & & 生 & & & & \\
\hline & 1500 & 2 & & & & 生 & & & & \\
\hline K. 181 & 5500 & $\sim$ & & & & 死 & + & + & + & \\
\hline \multirow{5}{*}{$\begin{array}{l}\text { K. } 182 \\
\text { K. } 183 \\
\text { K. } 184 \\
\text { K. } 185 \\
\text { K. } 186\end{array}$} & 2000 & 相 & & & & 生 & & & & \\
\hline & 2390 & 窟 & 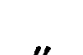 & ن. & 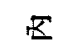 & 生 & & & & \\
\hline & 2260 & Sit & $n$ & $\overrightarrow{1}$ & 챌 & 生 & & & & 80 \\
\hline & 2240 & $\dot{\theta}$ & & $\stackrel{?}{?}$ & 愚 & 生 & & & & \\
\hline & 1760 & & & & & 死: & + & + & + & 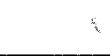 \\
\hline \multirow{3}{*}{$\begin{array}{l}\text { K. } 187 \\
\text { K. } 188 \\
\text { K. } 189\end{array}$} & 1700 & & & $\dot{0}$ & & 死 & + & + & + & \\
\hline & 1650 & & "' & $\bar{\delta}$ & " & 生 & & & & 67 \\
\hline & 1460 & & & $\dot{0}$ & & 生 & & & & \\
\hline \multirow{3}{*}{$\begin{array}{cc}\text { 對 } & \mathrm{A} \\
\prime \prime & \mathrm{B} \\
\prime \prime & \mathrm{C}\end{array}$} & 1510 & & & & $\sqrt{2}$ & 死 & + & + & + & \\
\hline & 1560 & & $\prime \prime$ & $\underset{-1}{-1}$ & 些 & 死 & + & + & + & 34 \\
\hline & 1450 & & & & 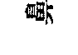 & 生 & & & & \\
\hline \multirow{2}{*}{$\begin{array}{ll}\prime \prime & \mathrm{D} \\
\prime \prime & \mathrm{E}\end{array}$} & 1520 & & $\|$ & 궁 & $\frac{\pi}{4}$ & 死 & + & + & + & 0 \\
\hline & 1775 & & & $\dot{0}$ & 賞 & 死 & + & + & + & 0 \\
\hline \multirow{2}{*}{$\begin{array}{ll}\prime \prime & \mathrm{F} \\
\prime \prime & \mathrm{G}\end{array}$} & 1610 & & "I & $\overline{8} \dot{0}$ & " & 死 $_{1}$ & + & + & + & 0 \\
\hline & 1700 & & & $\stackrel{\circ}{\circ}$ & & 死 & + & + & + & 0 \\
\hline
\end{tabular}

[註】符號八前表二同ジ 
ニ示スガ如キ成緽ヨ得タリ是卜同一筫驗八更八數回反復シタルモ殆ド同梯 ノ成績ニシテ結局經鼻感染二邺シテハ平均ノ防禦率タ示シタリ

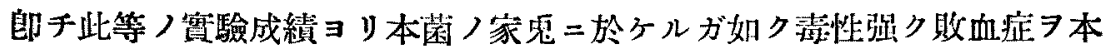
態トシ肺炎性ノ變化入單二是二隨件セル一部分症トシテ現ハル〉ガ如キ菌 䅅つ感染=對シテハ死菌虫疲效果ハ極メテ顯著ナルコトラ知りタリ（但シ 感染菌量稌リニ多量ナル場合バ效果少ナシ）然レ共敗血症习防禦スルト共 二旬:常確惯二肺炎性疾患ノ發現ヨモ防禦スルモノニハ非ザルガ如ク前記ノ 實䮑筙園＝於テ八斯ル例八認メザリシモ余等八所謂家禽てれら菌ノ家鬼感

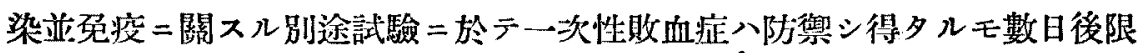
局性化膿性肺炎 タリ斯クノ如キ事惯ヨリ考察スル二本菌ノ家鬼二於ケルガ如ク一次性敗血 症 ヨ本態トスルモノニ於テ八死菌免疫 $=ヨ$ リ敗血症ノ成立巶千菌ノ血中侵 入及增殖 ズ殊二氣道二於くル菌ニ八作用シ得ズシテ一部ノ菌八最モ親和性ヨ有スル 呼吸器系統 $=$ 殘存シ是 $\exists$ 徐々 $=$ 限局性舺炎 7 發症シ洽王比較的毒性弱

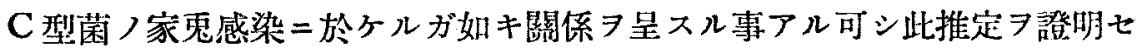
ンガ爲ニ八免疫動物體內二於ヶル菌ノ消長フ唯察スルニアルラ以テ次二余 等八免疫家鬼二經鼻感染 7 行ヒ隔日 $=$ 一定數〉動物 7 殺シ體內 =於ヶル菌 ノ消長习觀察シタリ其成䋶八第 13 垶二示スガ如シ

此成續二依レバ菌八接㗨後極ク短期間內八鼻腔及氣道=證明七ラル、モ

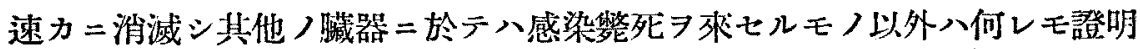
スル事能ハザリキ郎依之觀之前述ノ考察ハアリ得ベキモ甚ダ稀ナル場合二 シテ多クノ場合接種菌八速カニ體內ニ於テ消滅シ從テ感染八成立七ザルモ ノナル可シ

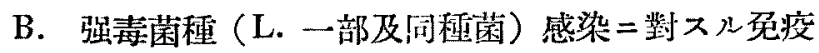

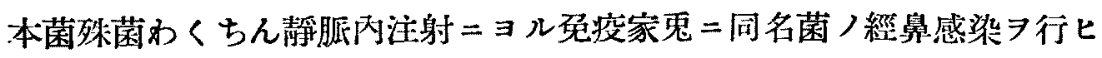
タル實驗成縝八第 14 表二示スガ如シ

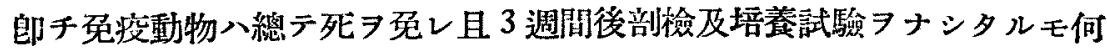


第 13 表强毒菌 (B. 全種) 死菌免疫家兔體內二於ケル菌ノ侵入及分如

\begin{tabular}{|c|c|c|c|c|c|c|c|c|c|c|c|c|c|c|c|c|c|c|c|c|c|c|c|c|c|}
\hline \multirow{2}{*}{$\begin{array}{l}\text { 家 } \\
\text { 榣 }\end{array}$} & \multirow{2}{*}{$\begin{array}{l}\text { 要 } \\
\text { 湿 }\end{array}$} & \multirow{2}{*}{ 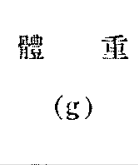 } & $\begin{array}{c}\text { 免没莯株 } \\
\text { 及 }\end{array}$ & \multicolumn{3}{|c|}{ 感染值株及力法 } & \multirow{2}{*}{$\begin{array}{l}\text { 接 種 後 } \\
\text { 解部迄， } \\
\text { 日數 }\end{array}$} & \multicolumn{8}{|c|}{ 體 內 } & \multicolumn{9}{|c|}{ ル菌, 分布 } & \multirow{2}{*}{$\begin{array}{c}\text { 生存索 } \\
(\%)\end{array}$} \\
\hline & & & ${ }_{\text {我 法 }}$ 及 & $\begin{array}{l}\text { 菌 } \\
\text { 株 }\end{array}$ & $\begin{array}{l}\text { 菌 } \\
\text { 量 }\end{array}$ & $\begin{array}{l}\text { 部 } \\
\text { 位 }\end{array}$ & & $\begin{array}{l}\text { 左 } \\
\text { 鼻 } \\
\text { 媵 }\end{array}$ & $\begin{array}{l}\text { 右 } \\
\text { 悬 } \\
\text { 腔 }\end{array}$ & $\begin{array}{l}\text { 咽 } \\
\text { 雏 }\end{array}$ & $\begin{array}{l}\text { 氣 } \\
上\end{array}$ & $\begin{array}{l}\text { 氣 } \\
\text { 下 }\end{array}$ & 肺 & \begin{tabular}{|l} 
胸 \\
喿
\end{tabular} & $\begin{array}{l}\text { 心 } \\
\text { 血 }\end{array}$ & 脾 & $\mathrm{JF}$ & 腎 & 腸間 & $\begin{array}{l}\text { 貲 } \\
\text { 出 } \\
\text { 淋 }\end{array}$ & $\begin{array}{l}\text { 熦 } \\
\text { 腺 }\end{array}$ & $\begin{array}{l}\text { 鼠 } \\
\text { 喛 } \\
\end{array}$ & $\begin{array}{l}\text { 腹 } \\
\text { 獎 }\end{array}$ & $\begin{array}{l}\text { 䐀 } \\
\text { 汁 }\end{array}$ & \\
\hline K. & 192 & 1870 & \multirow{16}{*}{ 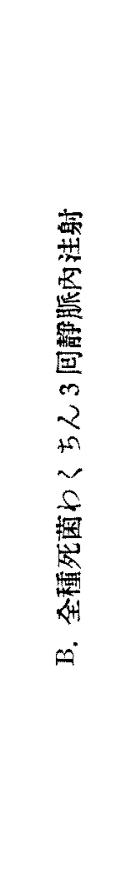 } & B. 全種 & $1 \mathrm{mg}$ & 鱼㬶內 & 1 & + & - & - & - & (4) & - & - & - & - & - & - & - & - & - & - & - & - & \multirow{16}{*}{94} \\
\hline $\mathrm{K}$. & 193 & 1840 & & " & " & " & " & - & - & - & - & - & - & - & - & - & - & - & - & - & - & - & - & - & \\
\hline $\mathrm{K}$ & 194 & 2425 & & " & $" \prime$ & " & 3 & + & + & - & - & - & - & - & - & - & - & - & - & - & - & - & - & - & \\
\hline $\mathrm{K}$. & 195 & 1400 & & $\prime \prime$ & $\prime \prime$ & $"$ & " & - & - & - & - & - & - & - & - & - & - & - & - & - & - & - & - & - & \\
\hline $\mathrm{K}$. & 196 & 1700 & & $"$ & " & " & 5 & - & - & - & - & - & - & - & - & - & - & - & - & - & - & - & - & - & \\
\hline $\mathrm{K}$. & 197 & 1575 & & " & $"$ & $" \prime$ & $\prime \prime$ & - & - & $\cdots$ & - & - & - & - & - & - & - & - & - & - & - & - & - & - & \\
\hline $\mathrm{K}$. & 198 & 1920 & & $\prime \prime$ & " & " & 7 & - & - & - & - & - & - & - & - & - & - & - & - & - & - & - & - & - & \\
\hline $\mathrm{K}$ & 199 & 1730 & & " & $\prime \prime$ & " & $" \prime$ & - & - & - & - & - & - & - & - & - & - & - & - & - & - & - & - & - & \\
\hline $\mathrm{K}$ & 200 & 1620 & & " & $" \prime$ & $\prime \prime$ & $\prime \prime$ & - & - & - & - & - & - & - & - & - & - & - & - & - & - & - & - & - & \\
\hline $\mathrm{K}$. & 201 & 1510 & & $\prime \prime$ & $\prime \prime$ & ' & 10 & - & - & - & - & - & - & - & - & - & - & - & - & - & - & - & - & - & \\
\hline K. & 202 & 1725 & & 'I & $\prime \prime$ & $\prime \prime$ & $\prime \prime$ & - & - & - & - & - & - & - & - & - & - & - & - & - & - & - & - & - & \\
\hline $\mathrm{K}$ & 203 & 1525 & & "I & " & $\prime \prime$ & 14 & - & - & - & - & - & - & - & - & - & - & - & - & - & - & - & - & - & \\
\hline $\mathrm{K}$. & 204 & 1400 & & $" 1$ & " & $\prime \prime$ & 3 日目粡死 & & & & & & $H$ & 卌 & m & & & & & & & & & & \\
\hline $\mathrm{K}$. & 205 & 1800 & & " & " & " & 14 & - & - & - & - & - & - & - & - & - & - & - & - & - & - & - & - & - & \\
\hline $\mathrm{K}$. & 206 & 1490 & & " & " & "l & 13日目獘死 & & & & & & - & - & - & & & & & & & & & & \\
\hline K. & 207 & 1650 & & $" \prime$ & $\prime \prime$ & $\prime \prime$ & 14 & - & - & - & - & - & - & - & - & - & - & - & - & - & - & - & - & - & \\
\hline 對 & $\mathrm{K}$ & 1450 & & " & " & $" \prime$ & 1 日目獘死 & & & & & & H & H & $\#$ & & & & & & & & & & \\
\hline$" \prime$ & I. & 1450 & & $" \prime$ & " & $" \prime$ & $" \prime$ & & & & & & $H$ & m & $\#$ & & & & & & & & & & 0 \\
\hline " & $\mathrm{M}$ & 1700 & & " & " & $" \prime$ & 2 日目笔死 & & & & & & $H$ & H & $H$ & & & & & & & & & & \\
\hline
\end{tabular}

〔註〕符萀八第 3 表二间ジ 
第 14 表 强毒菌（L. 細 14）=對スル同名菌死菌免学試驗

\begin{tabular}{|c|c|c|c|c|c|c|c|c|c|c|}
\hline \multirow{2}{*}{$\begin{array}{l}\text { 家 鬼 } \\
\text { 番 萀 }\end{array}$} & \multirow{2}{*}{ 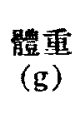 } & \multirow{2}{*}{$\begin{array}{ll}\text { 免 疫 } \\
\text { 菌株 } \\
\text { 及方法 }\end{array}$} & \multicolumn{3}{|c|}{ 慰染菌株及力法 } & \multirow{2}{*}{ 結果 } & \multicolumn{3}{|c|}{ 培 餐 所 見 } & \multirow{2}{*}{$\begin{array}{c}\text { 生存碎 } \\
(\%)\end{array}$} \\
\hline & & & 菌株 & 菌量 & 部位 & & 心血 & 肺 & 胸洯 & \\
\hline K. 457 & 2000 & 定 & L。細14 & $1 \mathrm{mg}$ & 夏㬶內 & 生 & & & & \\
\hline K. 458 & 2000 & 茂 & " & "' & " & 生 & & & & \\
\hline K. 459 & 1800 & 监 & $\prime \prime$ & $" \prime$ & " & 生 & & & & \\
\hline K. 460 & 1700 & 政 & "I & $\prime \prime$ & $\prime \prime$ & 生 & & & & \\
\hline K. 465 & 1450 & j & !" & $" \prime$ & " & 生 & & & & \\
\hline K. 466 & 1500 & $+n$ & $" \prime$ & $\prime \prime$ & " & 生 & & & & 100 \\
\hline K. 467 & 1500 & vo & $\prime \prime$ & $\prime \prime$ & $\prime \prime$ & 生 & & & & \\
\hline K. 468 & 1500 & 䀅 & $" \prime$ & $\prime \prime$ & $" 1$ & 生 & & & & \\
\hline K. 469 & 1500 & 岕 & "I & " & " & 生 & & & & \\
\hline K. 470 & 1500 & 票 & $" \prime$ & $" \prime$ & $"$ & 生 & & & & \\
\hline K. 471 & 1500 & $\dot{i}$ & "I & $\prime \prime$ & $"$ & 扯 & & & & \\
\hline 對 27 & 1500 & & " & "I & " & 死 & + & + & + & \\
\hline$\prime \prime \quad 28$ & 1450 & & $\prime \prime$ & $" \prime$ & " & 死 $_{3}$ & + & + & + & 0 \\
\hline
\end{tabular}

[註]符號八第 11 表二闹シ

レノ臓器ニ於テモ病變及菌习證朋スルコト能ハザリキ郎チ本菌ノ家兔二於 ケルガ如ク一次性急性大柋性胢炎习發症セシムルト共二速カ＝敗血症=陷

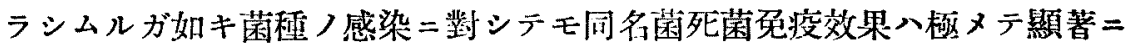

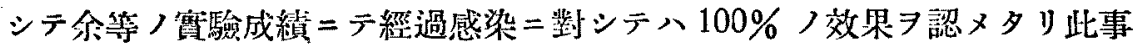
惯八速カ二致死的敗血症二進展セシムルガ如手菌種ニヨル急性肺炎二丵シ テハ死菌冤疫ハ荜ダ有效ナルヨ認メシムルモノナリ然レ其此場合二於テモ

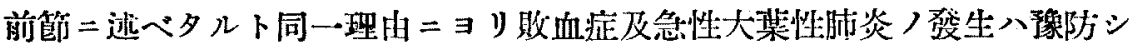
得ルモ全部必ズシモ氣道感染ニヨル限局性:シテ經過綬慢ナル化膿性加答 兒性郝炎ノ墢生入豫防シ得ザルモノナル可シ但シ本試驗 =於テハ斯ル例 認ムルコトナカリキ

\section{C. 搦毒囷（S. 江原）感染二對スル免疾}

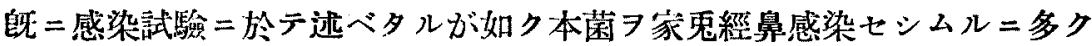
ノ場合感染整死

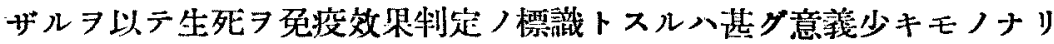




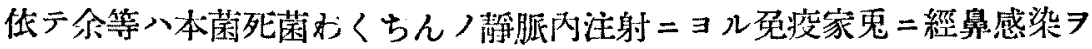

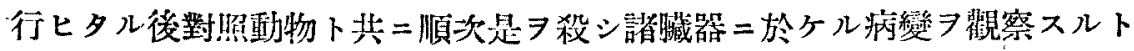

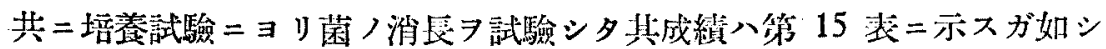

即チ表二示スガ如ク對照動物 1 頭二於テ 5 日目剖檢二際シ右肺 $=$ 限局性 化膿性肺炎及及癒着性肍膜炎 器二病變习認メタルモノナシ（倇疫家鬼入內 K. 293, K. 296 ノ 2 頭八夫

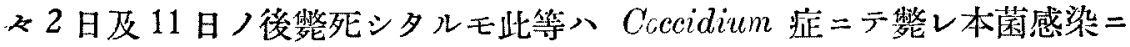
ヨル整死二ハ非ザル事ヨ認メタリ)

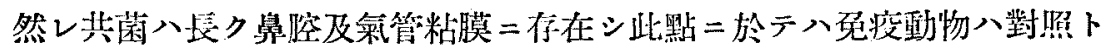

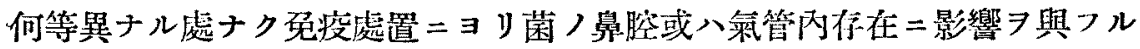
ガ如キ事䁇ハ認メラレザリキ前述ノ如ク對照動物中 1 頭八肺炎ヨ起シタル 二拘ラズ免疾動物二八斯ル者ナキ リタリト認メ得ザル =八非ザルモ元來本菌八經鼻感染ニヨリテ湖炎ヨ成生 セシムルコト琶ダ稀ニシテ從ツテ是习以テ其效果ヨ云ネスルハ不適當ナル 可ク寧口氣道二於ヶル菌ノ存在二影譥ナキ事實入本菌等ノ如ク呼吸器粘膜 =奇生シ此部 =炎性變化 7 生ゼシムル $シ$ 本態トスルモノ =アリテハ死菌免 疫效果ハ少キモノト認定スベキモノナリト思惟ス但シソノ經過习緩慢ナラ シメヌ次デ起ル可キ敗血症二對シテハ前節二記载シタル菌種二於アルガ如 ク相當效果アルモノナラン

D. 弱毒菌種 (Bact. bronchisepticus) 感染=對スル免疼

本試驗八前章 S. 汇原ノ場合卜全ク同樣二行ヒ唯經鼻感染ノミナラズ胸 腔內注射感染 $モ$ 數例＝就テ試驗シタリ而シテ其結果入第 16 表及第 17 表 ニ示スガ如ク前章 S. 江原ノ場合二於ケルト殆ド全ク同一ニシテ何等特別 ノ說朋フ要セズ唯此場合二於テハ病變ナキ場合ニ於テモ肺 ラル、事宽す追加スレバ足レリトス

向本試驗二於テハ各動物二就テ㨽檢二際シ血液

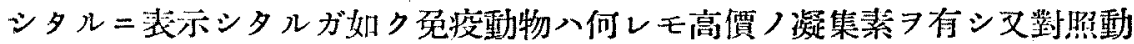

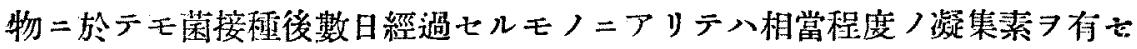




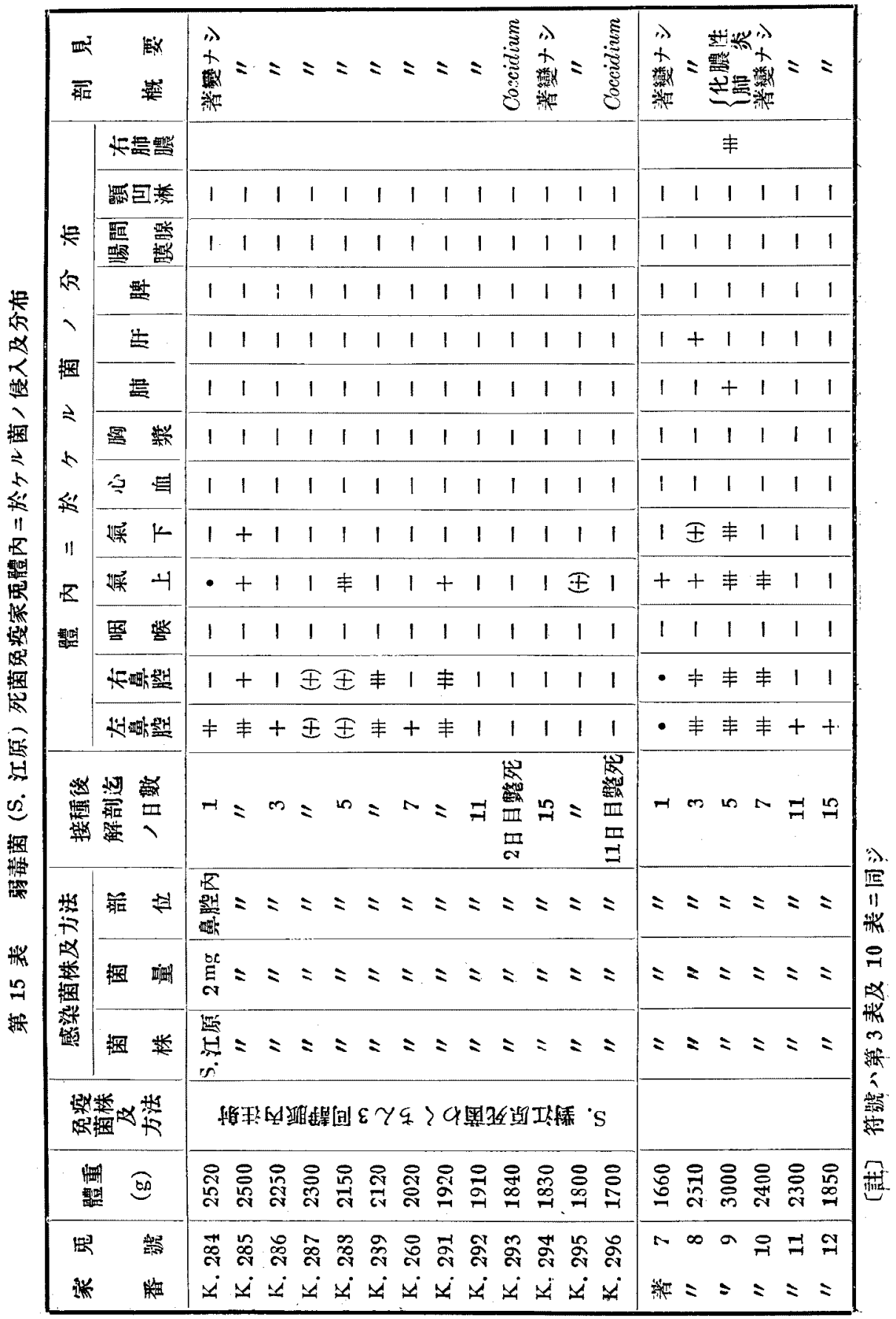




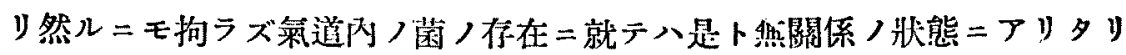

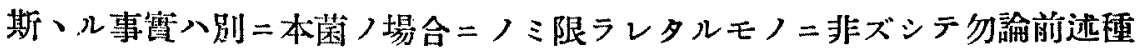
ネナル菌ノ場合二於テモアリタルモノナル可ク唯余等ガ夫等ノ場合二就テ 八試驗セザリシニ過ギザルモノニシテ此成績ニヨリテモ明カナルガ如ク死

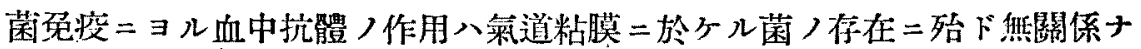
ル事习推定セシム從ツテ影血症及一次泩肺炎ヨり直二敗血症=移行スルガ 如キ菌種 感染 $=$ 對シテハ死菌免疫 $=ヨ ! テ$ 得ラル、血中抗體ノ作用八效 果顛著ナルモ菌入氣道二存在シ其部二病的變化 $ヨ$ 生ゼシムルガ如キ菌種， 感染 =對シテ八其效果㱠ド見ル可カラザルハ上进つ惯驗ニョリテモ明カナ ル可シ

\section{III. 總括及結論}

以上記载シタル霓驗成績

（1）B. 全種/如キ表性强キ菌種 $习$ 家兔二接種スル=接種力法/如何

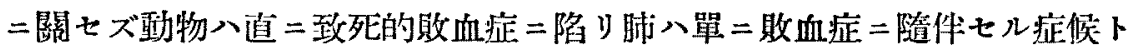
シテ充血水腫 7 起ス二過ギズ郎チ斯ル菌種ヨ以テ八定型的肺炎 ムルコト能ハズ而シテ斯クノ如キ敬血症死＝對シテハ同名菌死菌免疫八逻 ダ有效 =シテ經鼻感染等ノ如キ自然感染經路 $=$ 準ジタル 感染 $=$ 對シテハ 殆ド $100 \%$ ノ豫防效果アリ

（2）前者ヨリ稍々毒性弱キ L. 一部ノ如キ菌種ヨ以テスレバ胸整內注 射 $ヨ$ リ最モ確實 = 定型的急性大葉性肺炎习成生センムルコト 得經鼻感 染ニヨリテハ传常必ズシモ定型的肺炎ヨ惹起七ズシテ上部氣道及其附込，

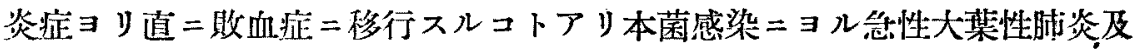
敗血症ニ對シテモ同名菌死菌冤疾入甚ダ有效ナリ

（3）菌力弱キS. 汇原ノ如キ菌犁ノ經鼻感染二於テ八菌八長ク呼吸器 粘膜=止マリ其處二一程度發育增殖シ逐二八經過緩慢ナル化膿性氣管枝肺 炎ヨ生ゼシムルコトアルモ旬常確實ナラズ而シテ此種ノ菌感染=ヨル肺炎 ノ病型 =對シテハ死菌免疫八大ナル效果ナキモノ、如ク推定セラル其ノ故 
第 16 表弱苗菌 (Bact. bronchisepticus) 死菌免疫家鬼體内二於ヶル菌, 侵入及分布

\begin{tabular}{|c|c|c|c|c|c|c|c|c|c|c|c|c|c|c|c|c|c|c|c|c|c|c|c|c|c|c|c|c|c|c|c|c|c|c|c|c|c|c|c|c|}
\hline \multirow{2}{*}{\begin{tabular}{ll} 
家 & \multicolumn{1}{c}{} \\
番 & \\
\end{tabular}} & \multirow{2}{*}{$\begin{array}{c}\text { 體 重 } \\
\text { (g) }\end{array}$} & \multirow{2}{*}{$\begin{array}{ll}\text { 免 } & \text { 疫 } \\
\text { 菌 } & \text { 株 } \\
\text { 及方法 }\end{array}$} & \multicolumn{3}{|c|}{ 感染菌株及方法 } & \multicolumn{15}{|c|}{ 接種後鼻脉及咽啹二於ヶル菌，消長 } & \multirow{2}{*}{$\begin{array}{l}\text { 接種後 } \\
\text { 解剖迄 } \\
\text { 一日数 }\end{array}$} & \multicolumn{17}{|c|}{ 體内 内於ヶル菌，分有 } & \multirow{2}{*}{$\begin{array}{l}\text { 剖 見 } \\
\text { 概 要 }\end{array}$} & \multirow{2}{*}{$\begin{array}{l}\text { 彪分時 } \\
\text { 血 清 } \\
\text { 凝集價 }\end{array}$} \\
\hline & & & 菌株 & 菌量 & 部位 & 部位 & 1 & 2 & 3 & 4 & 5 & 6 & 7 & 8 & 9 & 10 & 11 & 12 & 13 & 14 & & $\begin{array}{l}\text { 点 } \\
\text { 解 }\end{array}$ & 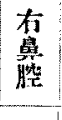 & 咽 & \begin{tabular}{|l} 
氣 \\
上.
\end{tabular} & $\begin{array}{l}\text { 氣 } \\
\text { 下 }\end{array}$ & 肺 & \begin{tabular}{|l} 
胸 \\
漿 \\
\end{tabular} & $\begin{array}{l}\text { 心 } \\
\text { 血 }\end{array}$ & 脾 & 肝 & 堅 & $\mid$ & $\begin{array}{l}\text { 腸間 } \\
\text { 膜腺 }\end{array}$ & 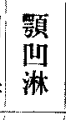 & \begin{tabular}{|l|} 
腋 \\
蕰 \\
湶 \\
\end{tabular} & \begin{tabular}{|l|} 
\\
䶆 \\
腺
\end{tabular} & $\begin{array}{l}\text { 僣 } \\
\text { 汁 }\end{array}$ & & \\
\hline K1. 28 & 1450 & \multirow{6}{*}{ 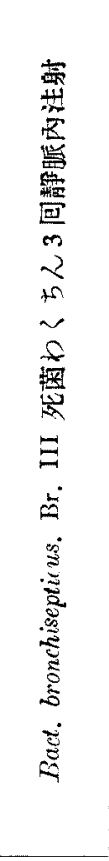 } & Br. III & $2 \mathrm{mg}$ & 兽腔內 & 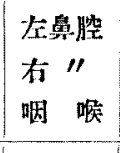 & $\begin{array}{l}- \\
- \\
-\end{array}$ & & $\begin{array}{l}+1 \\
+; \\
-\end{array}$ & $\begin{array}{l}+ \\
- \\
-\end{array}$ & $\begin{array}{l}- \\
+ \\
-\end{array}$ & $\begin{array}{l}- \\
- \\
-\end{array}$ & $\begin{array}{l}- \\
- \\
-\end{array}$ & $\mid \begin{array}{l}- \\
- \\
-\end{array}$ & $\begin{array}{l}+ \\
- \\
- \\
\end{array}$ & $\begin{array}{l}- \\
- \\
-\end{array}$ & $\begin{array}{l}- \\
- \\
-\end{array}$ & & & & 11 & \# & 册 & - & - & - & - & - & - & - & - & - & - & - & - & - & - & - & 㵔變ナシ & 10.000 \\
\hline $\mathrm{Kb} .29$ & 1490 & & $"$ & " & $"$ & 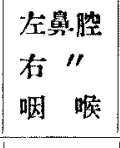 & $\begin{array}{l}- \\
- \\
-\end{array}$ & & $\begin{array}{l}+39 \\
+1 \\
-\end{array}$ & $\begin{array}{l}- \\
- \\
-\end{array}$ & $\begin{array}{l}+ \\
- \\
-\end{array}$ & $\begin{array}{l}- \\
- \\
-\end{array}$ & $\begin{array}{l}- \\
- \\
- \\
\end{array}$ & $\mid \begin{array}{l}- \\
- \\
-\end{array}$ & $\begin{array}{l}- \\
- \\
-\end{array}$ & $\begin{array}{l}- \\
- \\
- \\
\end{array}$ & $\begin{array}{l}+ \\
- \\
-\end{array}$ & & & & " & 卅 & m & - & 曲 & \# & - & - & - & - & - & - & - & - & - & - & - & - & $"$ & 20.000 \\
\hline $\mathrm{Kb}, 30$ & 1550 & & " & 1 & 粅膛内 & \begin{tabular}{|l|l} 
左鼻胑 \\
右” \\
咽 啹
\end{tabular} & $\begin{array}{l}- \\
- \\
-\end{array}$ & & $\begin{array}{l}- \\
- \\
-\end{array}$ & $\begin{array}{l}+ \\
- \\
-\end{array}$ & $\begin{array}{l}- \\
- \\
-\end{array}$ & $\begin{array}{l}+25 \\
+2 \\
-\end{array}$ & $\begin{array}{l}- \\
- \\
-\end{array}$ & $\begin{array}{l}- \\
- \\
-\end{array}$ & $\begin{array}{l}- \\
- \\
- \\
\end{array}$ & $\begin{array}{l}+ \\
- \\
- \\
\end{array}$ & $\begin{array}{l}+ \\
+9 \\
- \\
\end{array}$ & & & & $"$ & Ht & H & - & m & 册 & H & - & - & - & - & $1-$ & - & - & - & - & - & - & $"$ & " \\
\hline $\mathrm{Kb}, 39$ & 2200 & & $"$ & $"$ & " & 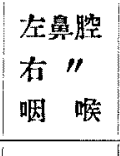 & $\begin{array}{l}- \\
- \\
-\end{array}$ & $\begin{array}{l}- \\
- \\
-\end{array}$ & & $\begin{array}{l}- \\
- \\
-\end{array}$ & $\begin{array}{l}- \\
- \\
- \\
\end{array}$ & $\begin{array}{l}- \\
- \\
-\end{array}$ & $\begin{array}{l}- \\
- \\
-\end{array}$ & $\begin{array}{l}- \\
- \\
-\end{array}$ & \begin{tabular}{|l|}
+2 \\
- \\
- \\
\end{tabular} & $\begin{array}{l}- \\
- \\
- \\
\end{array}$ & $\begin{array}{l}- \\
- \\
-\end{array}$ & $\begin{array}{l}- \\
- \\
-\end{array}$ & $\begin{array}{l}- \\
- \\
-\end{array}$ & $\begin{array}{l}- \\
- \\
-\end{array}$ & 14 & m & W & - & H & - & - & $1-$ & - & - & - & - & - & - & - & - & - & - & " & " \\
\hline $\mathrm{Kb}, 41$ & 1850 & & " & $"$ & $"$ & $\mid \begin{array}{l}\text { 左畺腃 } \\
\text { 有 } \\
\text { 咽 }\end{array}$ & $\begin{array}{l}+ \\
- \\
- \\
\end{array}$ & $\begin{array}{l}1+ \\
- \\
- \\
\end{array}$ & & $\begin{array}{l}- \\
- \\
- \\
\end{array}$ & $\mid \begin{array}{l}- \\
- \\
-\end{array}$ & $\begin{array}{l}- \\
- \\
-\end{array}$ & $\begin{array}{l}- \\
- \\
-\end{array}$ & $\begin{array}{l}- \\
- \\
-\end{array}$ & $\begin{array}{l}- \\
+1 \\
-\end{array}$ & $\begin{array}{l}- \\
- \\
-\end{array}$ & $\begin{array}{l}- \\
- \\
-\end{array}$ & $\begin{array}{l}- \\
- \\
-\end{array}$ & $\begin{array}{l}- \\
- \\
-\end{array}$ & $\begin{array}{l}- \\
- \\
-\end{array}$ & $"$ & - & - & - & - & - & - & - & - & - & - & - & - & - & -1 & - & - & - & $"$ & " \\
\hline Kl. 43 & 1520 & & $"$ & " & " & $\begin{array}{l}\text { 左鼻䏶 } \\
\text { 有" } \\
\text { 咽 㘈 }\end{array}$ & $\begin{array}{l}- \\
- \\
-\end{array}$ & $\begin{array}{l}- \\
- \\
-\end{array}$ & & & & & & & & & & & & & $\left|\begin{array}{cc}3 & \text { 日目 } \\
\text { 整 } & \text { 死 }\end{array}\right|$ & - & - & - & - & - & - & - & - & - & - & - & - & - & - & - & - & - & $"$ & $"$ \\
\hline 對 $\quad \Lambda$ & 1820 & & $"$ & 2 & 筫脿刚 & $\begin{array}{l}\text { 左鼻䏶 } \\
\text { 右” } \\
\text { 咽 喉 }\end{array}$ & $\begin{array}{l}- \\
- \\
-\end{array}$ & & $\begin{array}{c}+7 \\
+1 \\
-\end{array}$ & $\begin{array}{l}+ \\
- \\
-\end{array}$ & $\begin{array}{l}- \\
+3 \\
-\end{array}$ & $\begin{array}{l}- \\
- \\
-\end{array}$ & $\begin{array}{l}- \\
- \\
-\end{array}$ & $\begin{array}{l}- \\
- \\
-\end{array}$ & \begin{tabular}{|l|}
- \\
- \\
- \\
\end{tabular} & $\begin{array}{l}+ \\
- \\
-\end{array}$ & $\begin{array}{l}- \\
- \\
-\end{array}$ & & & & 11 & m & m & - & m & H. & - & - & - & - & - & - & - & - & - & -1 & - & - & $"$ & 200 \\
\hline$" \mathrm{~B}$ & 2200 & & $"$ & $"$ & $"$ & 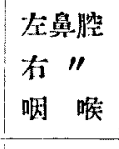 & $\begin{array}{l}- \\
- \\
-\end{array}$ & & $\begin{array}{l}- \\
- \\
-\end{array}$ & $\begin{array}{c}+ \\
+3 \\
-\end{array}$ & $\begin{array}{l}- \\
- \\
-\end{array}$ & $\begin{array}{l}- \\
- \\
-\end{array}$ & $\begin{array}{l}- \\
- \\
-\end{array}$ & $\mid \begin{array}{l}- \\
- \\
-\end{array}$ & $\begin{array}{l}- \\
- \\
-\end{array}$ & $\begin{array}{l}- \\
- \\
-\end{array}$ & $\begin{array}{l}- \\
- \\
- \\
\end{array}$ & & & & $"$ & +3 & W & - & - & - & - & - & - & - & - & - & - & - & - & - & - & - & $"$ & \\
\hline$" \mathrm{C}$ & 2190 & & $"$ & 1 & 物堙网 & 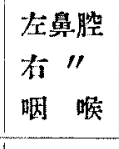 & $\begin{array}{l}+ \\
- \\
-\end{array}$ & & $\begin{array}{l}- \\
- \\
-\end{array}$ & $\begin{array}{l}- \\
+52 \\
-\end{array}$ & $\mid \begin{array}{l}- \\
- \\
-\end{array}$ & $\begin{array}{l}+ \\
+ \\
-\end{array}$ & $\begin{array}{l}- \\
- \\
-\end{array}$ & $\left|\begin{array}{l}+3 \\
- \\
-\end{array}\right|$ & $\begin{array}{l}- \\
- \\
-\end{array}$ & $\begin{array}{l}- \\
- \\
-\end{array}$ & $\begin{array}{l}+ \\
+ \\
-\end{array}$ & & & & " & H & H & - & m & H & + & - & - & - & - & - & - & - & - & - & - & - & $"$ & 2000 \\
\hline " 13 & 1400 & & $"$ & " & $"$ & $\begin{array}{l}\text { 左县腔 } \\
\text { 不 } \\
\text { 咽 }\end{array}$ & $\begin{array}{l}- \\
- \\
-\end{array}$ & $\begin{array}{l}- \\
- \\
- \\
\end{array}$ & $\begin{array}{l}- \\
- \\
-\end{array}$ & $\begin{array}{l}- \\
- \\
-\end{array}$ & $\begin{array}{l}- \\
- \\
-\end{array}$ & $\begin{array}{l}- \\
- \\
-\end{array}$ & & & \begin{tabular}{l|} 
m \\
m \\
-
\end{tabular} & & $\begin{array}{l}- \\
+ \\
-\end{array}$ & $\begin{array}{l}- \\
+ \\
-\end{array}$ & & & 14 & (t) & (t) & - & H & + & m & - & - & - & - & - & - & $1-$ & - & - & - & (t) & 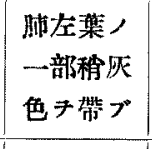 & $"$ \\
\hline$" \mathrm{E}$ & 1500 & & $"$ & $"$ & $"$ & \begin{tabular}{|l|} 
左鼻膛 \\
有 \\
咽
\end{tabular} & $\begin{array}{l}- \\
- \\
- \\
\end{array}$ & $\begin{array}{l}- \\
- \\
- \\
\end{array}$ & $\begin{array}{l}- \\
- \\
-\end{array}$ & $\begin{array}{l}- \\
- \\
- \\
\end{array}$ & $\begin{array}{l}- \\
- \\
-\end{array}$ & $\begin{array}{l}- \\
- \\
-\end{array}$ & & & $\begin{array}{l}- \\
- \\
-\end{array}$ & & $\begin{array}{l}- \\
- \\
-\end{array}$ & $\begin{array}{l}+ \\
H \\
- \\
\end{array}$ & & & \begin{tabular}{|l|}
14 日且 \\
整
\end{tabular} & \# & \# & - & \# & HI & m & - & - & • & - & $\cdot$ & • & \# & - & - & - & m & \begin{tabular}{|c|} 
化 膿 性 \\
緇䧽素性 \\
助膜肺笑
\end{tabular} & \\
\hline
\end{tabular}

〔註】符號八第 3 表及第 10 表二同 
第 17 表弱瑇菌 (Bact. bronchisepticus) 死菌免疫管兔體内二於ケル菌，侵入及分布

\begin{tabular}{|c|c|c|c|c|c|c|c|c|c|c|c|c|c|c|c|c|c|c|c|c|c|c|}
\hline \multirow{2}{*}{$\begin{array}{l}\text { 家 } \\
\text { 番 }\end{array}$} & \multirow{2}{*}{$\begin{array}{l}\text { 爱 } \\
\text { 號 }\end{array}$} & \multirow{2}{*}{$\begin{array}{c}\text { 體 重 } \\
(\mathrm{g})\end{array}$} & \multirow{2}{*}{$\begin{array}{c}\text { 免疫菌怢 } \\
\text { 及 } \\
\text { 发 法 }\end{array}$} & \multicolumn{3}{|c|}{ 感染菌株及方法 } & \multirow{2}{*}{$\begin{array}{l}\text { 接 種 後 } \\
\text { 解剖迄 } \\
\text { 日 數 }\end{array}$} & \multicolumn{13}{|c|}{ 體内二於ケル菌，分布 } & \multirow{2}{*}{$\begin{array}{l}\text { 處分時， } \\
\text { 血清， } \\
\text { 凝集 傮 }\end{array}$} & \multirow{2}{*}{$\begin{array}{l}\text { 剖 } \\
\text { 見 } \\
\text { 概 要 }\end{array}$} \\
\hline & & & & $\begin{array}{l}\text { 菌 } \\
\text { 株 }\end{array}$ & $\begin{array}{l}\text { 菌 } \\
\text { 量 }\end{array}$ & $\begin{array}{l}\text { 部 } \\
\text { 位 }\end{array}$ & & 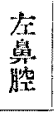 & 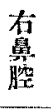 & 咽 & $\begin{array}{l}\text { 氣 } \\
\text { 上 }\end{array}$ & $\begin{array}{l}\text { 雬 } \\
\text { 下 }\end{array}$ & 肺 & $\begin{array}{l}\text { 胸 } \\
\text { 獎 }\end{array}$ & 心 & 脾 & 朋 & 㯏 & 晹間 & $\begin{array}{l}\text { 顎 } \\
\text { 淋 }\end{array}$ & & \\
\hline $\mathrm{K}$. & 44 & 1920 & 窟 & Br. III & $2 \mathrm{mg}$ & 兽腔內 & 1 & \# & \# & - & - & - & - & - & - & - & - & - & - & - & 20.400 & 著變ナシ \\
\hline $\mathrm{K}$. & 45 & 1950 & 䇥 & $" \prime$ & $" \prime$ & $\prime \prime$ & " & m & - & - & H. & 世 & H & - & - & - & - & - & - & - & $"$ & $"$ \\
\hline $\mathrm{K}$. & 46 & 1980 & 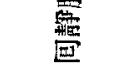 & " & $"$ & " & 3 & \# & + & - & H & + & - & - & - & - & - & - & - & - & " & $\prime \prime$ \\
\hline $\mathrm{K}$. & 47 & 1440 & 2 & $"$ & " & " & " & \# & $\#$ & - & - & - & - & - & - & - & - & - & - & - & $\prime \prime$ & " \\
\hline $\mathrm{K}$. & 48 & 1560 & 2 & $" \prime$ & $"$ & $"$ & 5 & H & H & - & \# & + & - & - & - & - & - & - & - & - & " & $\prime \prime$ \\
\hline $\mathrm{K}$. & 49 & 1420 & $\underset{\text { 涸 }}{f}$ & " & " & " & $"$ & \# & $H$ & - & H & H & H & - & - & - & - & - & - & - & $"$ & " \\
\hline K. & 50 & 1415 & 苳 & " & " & " & 7 & W & $\mathrm{HH}$ & - & m & H & + & - & - & - & - & - & - & - & " & " \\
\hline K. & 51 & 1590 & 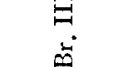 & " & " & " & $"$ & H & $H$ & - & H & m & + & - & - & - & - & - & - & - & " & $\prime \prime$ \\
\hline $\mathrm{K}$. & 52 & 1550 & 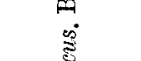 & " & " & " & 10 & $\#$ & H & - & $\mathrm{m}$ & m & + & - & - & - & - & - & - & - & " & $"$ \\
\hline $\mathrm{K}$. & 53 & 1540 & 芯, & $"$ & " & "I & $"$ & + & H & - & HI & H & H & - & - & - & - & - & - & - & $"$ & $"$ \\
\hline $\mathrm{K}$. & 54 & 1900 & 芯 & $"$ & $"$ & " & 14 & 州 & H & - & \# & \# & - & - & - & - & - & - & - & - & " & " \\
\hline $\mathrm{K}$ & 55 & 1540 & $\begin{array}{l}5 \\
\text { E. }\end{array}$ & $\prime \prime$ & $"$ & " & 15 & m & \# & + & m & $\#$ & - & - & - & - & - & $=$ & - & - & $"$ & " \\
\hline K. & 56 & 1960 & 8 & $"$ & " & $\prime \prime$ & 1 & + & $H$ & - & - & - & - & - & - & - & - & - & - & - & " & " \\
\hline 對 & $\mathrm{F}$ & 1580 & & " & $" \prime$ & $"$ & 1 & H & H & - & H & + & - & - & - & - & - & - & - & - & & " \\
\hline " & G & 1600 & & " & " & " & 3 & + & H & - & $H$ & m & \# & - & $(+)$ & - & - & - & - & - & 1000 & " \\
\hline$"$ & II & 1460 & & $"$ & " & " & 5 & H & H & - & H & \# & \# & - & - & - & - & - & - & - & 2000 & " \\
\hline$"$ & $\mathrm{~K}$ & 1485 & & " & " & $"$ & 7 & m & m & - & m & m & H & - & - & - & - & - & - & - & & $"$ \\
\hline$" \prime$ & $\mathrm{L}$ & 1580 & & " & " & " & 10 & m & \# & - & - & - & $H$ & - & - & - & - & - & - & - & 2000 & " \\
\hline$"$ & M & 1490 & & " & " & " & 14 & H & $+i$ & + & tit & - & - & - & - & - & - & - & - & - & 200 & " \\
\hline$" \prime$ & $\mathrm{N}$ & 1525 & & $"$ & " & " & 15 & $m$ & HI & H & m & H & H & - & - & - & - & - & - & - & 100 & $"$ \\
\hline
\end{tabular}

〔註〕符號ハ第 3 表二同ジ 
八星疫動物 =於テモ對照ト全ク同一二辰ク呼吸器粘膜二接種菌 7 保有シ肺 炎八是ヨリ進展スル 以テナリ

（4）殆ド病原性ナキ Bact. bronchisept cus ノ如キ菌種ノ經鼻感染二於 テハ前者ト殆ド同樣ニシテ菌ハ長ク呼吸器粘膜二止マリ且其處二發育鹪殖 スルモ祮ド無害ノ状態ニアリ本菌ノ場合二於テモ同名菌死菌免厒效果八前 者卜同樈ニシテ星疫動物ニアリテモ長ク呼吸器粘膜二接種菌

以上ノ賽驗成續ヨリ余等八次ノ如ク綃諭セントス

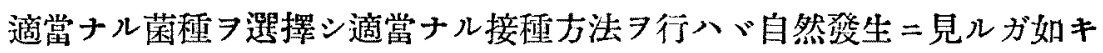
種くナル病型ノ脯炎 7 家鬼二賽驗的二成生セシムル事 等種ネナル病型入肋㷋性疾患二對スル资疫效果 7 實驗スルコトヨ得可シ而 シテ余等ノ試驗二於テハ急性敗血症二隨件シ又八一次性二發症スル急性大 葉性肺炎ノ發生二對シテハ死菌免疫八相當效果アルモ主トシテ菌ガ氣道= 限局シ徐々二進展スル慢性化膿性氣管枝胡炎ノ發生二對シテ大ナル效果ナ キモノノ、如シ

（稿

\section{主 要 文 獻}

(1) Wollstein, Martha \& Meltzer: J. Exp. Med., 1912, 16, 126.

(2) Winternitz u. Hirschfelder: Ibid., 1913, 17, 657.

(3) Blake \& Cecil : Ibid,., 1920, 31, 403.

(4) Gay \& Rhodes: J. Inf. Dis, 1921, 29, 217.

(5) Permar: J. Med. Reseurch., 1923, 44, 1.

（6）山林：日本微生物病理學會猚誌 (大正 12 年), 17, 337.

(7) Johnes: J. Fxp. Med., 1924, 39, 725.

（8）中回：日本微生物病理學會雑婄（昭和 9年）, 28, 155.

(9) Stillman \& Schulz: J. Exp. Med., 1925, 57, 238.

(10) 田中: J. Inj. Dis., 1926, 38, 389.

(11) $" \prime$ : Ibid., 1926, 38, 409.

(12) Webster: J. Exp. Med., 1926, 43, 555.

(13) " : Ibid., 1926, 43, 573.

(14) Bailey: Amer. J. Hyg., 1927, 7, 370.

(15) Bull \& Mckee: Ibid., 1927, 7, 627.

(16) Bailey \& Cheng: Ibid., 1928, 8, 485.

: Ibid., 1928, 8, 723 . 
(18) Bull \& Mckee: Ibid., 1929, 9, 49.0.

(19) " : Ibid., 1929, 10, 229.

(20) Stillman \& Branch: J. Exp. Med., 1925, 40, 733.

(21) Griffith: J. Hyg., 1926, 1, 25.

(22) Neufeld u. Kuhn: Zschr. Hyg. u.Infekt., 1934, 116, 697.

(23) Ochi: J. Jap. Soc. Vet. Sei., 1933, 12, 185. 


\title{
Experimenntal studies on Production of, and Immunization against Pneumonia in Rabbits.*
}

\author{
By \\ Y. Ochi and N. ImaI. \\ (From the Government Institute for Veterinary Research, \\ Chosen, Japan. Divector: Dr. T. Konno.)
}

(Received for publication, November 24, 1936)

Employing the following 4 kinds of organisms which have different degree of virulence, we investigated the production of the various forms of pneumonia in rabbits, as well as immunization.

The strains used:

(A) "B. Zenshu" This is a highly virulent organism isolated from swine dying of acute pneumonia and belongs to Type $B$ of Pasteurella by Ochi's classification.

(B) "L. Ichibu" This is also a highly pathogenic organism isolated from rabbit septicemia, but its virulence is not so high as that of the former.

(C) "S. Kogen" This is a low virulent strain isolated from swine dying of so-called swine-plague and belongs to Type $\mathrm{C}$ of Pasteurella by the same classification.

(D) Bact. bronchisepticus. This strain was isolated from the trachea of normal rabbits and is almost non-virulent.

The results obtained from the present experiment can be summarized as follows :

(1) Rabbits inoculated with highly virulent organism such as "B. Zenshu" either intrapleurally, intranasally, intravenously, or intraperitoneally die in 12 to 30 hours with all the signs of a rapid septicemia and fail to develop the typical pneumonia.

* Japanese original, pp. $32-60$ 
Intravenous vaccination with heat-killed vaccine of this organism gives definite protection against septicemia caused by the same organism.

(2) Acute lobar pneumonia is produced consistently in the rabbits by intrapleural injection of the organism such as " $\mathrm{L}$. ichibu", the rabbits inoculated intranasally do not develop pneumonia in most cases, but die of septicemia.

Immunization with the killed vaccine is also quite effective against such forms of pneumonia.

(3) When a low virulent organism such as "S. Kogen" is inoculated intranasally to rabbits, they fail to develop acute lobar pneumonia or septicemia and in many cases they develop chronic purulent bronchopneumonia.

It is considered that heat-killed vaccine has little value in protecting the animals against such forms of pneumonia, because the inoculated animals carry the organisms in their respiratory tracts for a long time as do the animals not inoculated.

(4) The rabbits inoculated intranasally with Bact. bronchisepticus do, in no instance, develop pneumonia though carrying the organism in their respiratory tracts.

In these cases inoculation with killed vaccine does notinsure against such organisms in the respiratory tract. 